\title{
Hydrogeochemical characteristics of a volcanic-sedimentary aquifer with special emphasis on Fe and Mn content: A case study in Mexico
}

\author{
M.V. Esteller*, N. Kondratenko, J.L. Expósito, M. Medina, M.A. Martin del Campo \\ Centro Interamericano de Recursos del Agua (CIRA), Facultad de Ingeniería, Universidad Autónoma del Estado de México, Cerro Coatepec S/N, 50130 Toluca, Mexico
}

\section{A R T I C L E I N F O}

\section{Keywords:}

Hydrochemistry

Volcanic-sedimentary aquifer

Redox conditions

Fe and Mn

Anthropogenic inputs

\begin{abstract}
A B S T R A C T
Previous studies performed on the volcanic-sedimentary aquifer of the Tenancingo Valley (Mexico) reports high concentrations of $\mathrm{Fe}, \mathrm{Mn}$, and $\mathrm{NO}_{3}{ }^{-}$, and water from several wells receives purification treatments due to presence of $\mathrm{Fe}$ and $\mathrm{Mn}$. These studies have not achieved conclusive results regarding the origin of Fe and $\mathrm{Mn}$, nor have hydrogeochemical evaluations of the aquifer been performed. The present study aimed to evaluate the physicochemical characteristics of the water and identify the geochemical processes that determine presence of Fe and $\mathrm{Mn}$ in groundwater. This characterization was based on physicochemical data from well and spring samples (16 samples) during dry and rainy seasons (June and November 2012, respectively).

The EC, temperature and $\mathrm{pH}$ ranged from 125 to $793 \mu \mathrm{S} \mathrm{cm}{ }^{-1}, 14.5$ to $24.9{ }^{\circ} \mathrm{C}$ and 6.5 to $8.5 \mathrm{pH}$ units, respectively. The Eh values ranged from -219 to $327 \mathrm{mV}$, indicating the existence of both reducing and oxidizing zones. Presence of Fe and Mn was detected in both springs and wells; concentrations were higher in well, exceeding $4 \mathrm{mg} \mathrm{Fe} \mathrm{L}^{-1}$ and $0.5 \mathrm{mg} \mathrm{Mn} \mathrm{L}^{-1}$. Content of Si ranged from 12 to $47 \mathrm{mg} \mathrm{L}^{-1}$.

A model of the hydrogeochemical behavior of the aquifer was created to highlight the following: i) processes involved in water-rock interactions, including fluctuations in silicate levels that determine anionic and cationic content of water, and ii) redox reactions as the major control processes of Fe and $\mathrm{Mn}$.

Water quality for human use is restricted by Fe and Mn content and $\mathrm{pH}$. For irrigation use, significant limitations were not presented.
\end{abstract}

\section{Introduction}

Hydrogeochemistry provides tools to enhance knowledge of the physicochemical composition of water and its recharge conditions, origin, residence time and potential mixing in groundwater systems. In aquifers under intense exploitation, hydrogeochemistry is also used to identify processes resulting in contamination or modification of the physicochemical characteristics of water (Ortega-Guerrero, 2009; Dassi, 2011), and in this way, contributes towards a more complete perspective of the origin, behavior and evolution of groundwater.

Hydrogeochemistry allows probing physicochemical composition of volcanic-sedimentary aquifers, which are frequently found to have high concentrations of undesirable and potentially toxic elements, such as arsenic, vanadium, fluoride, iron and manganese, among others (Esteller and Andreu, 2005; Vivona et al., 2007; Ortega-Guerrero, 2009; Parisi et al., 2011; Cinti et al., 2015; Morales-Arredondo et al., 2016); these restrict the use of groundwater as a supply source for human, agricultural and industrial uses.

When volcanic rocks are present, the cationic fraction tends to be more soluble in groundwater than the anionic fraction (Marrero, 2010). For example, water circulating through basalts and trachytes receives a higher contribution of $\mathrm{Mg}^{2+}$ than $\mathrm{Ca}^{2+}$, while water circulating through andesites tends to have a high $\mathrm{Na}^{+}$content (Appelo and Postma, 2005; Marrero, 2010). In this aquifers, the alteration of silicates is the most relevant process controlling the chemistry of groundwater, and furthermore, feldspars (plagioclases), as well as olivine, augite (pyroxene) or hornblende (amphibole), are easier to attack than quartz (Sonkamble et al., 2012), also evidenced by the silicate alteration sequence of Goldich (Appelo and Postma, 2005).

This process of silicate alteration may be represented by the following reactions (Appelo and Postma, 2005; Rahman et al., 2011; Sonkamble et al., 2012):

$2 \mathrm{NaAlSi}_{3} \mathrm{O}_{8}+2 \mathrm{CO}_{2}+11 \mathrm{H}_{2} \mathrm{O} \rightarrow 2 \mathrm{Na}^{+}+2 \mathrm{HCO}_{3}{ }^{-}+\mathrm{Al}_{2} \mathrm{Si}_{2} \mathrm{O}_{5}(\mathrm{OH})_{4}+4 \mathrm{H}_{4} \mathrm{SiO}_{4}$ Albite Kaolinite

\footnotetext{
* Corresponding author.

E-mail addresses: vicenta13@prodigy.net.mx, mvestellera@uaemex.mx (M.V. Esteller).
} 
$3 \mathrm{NaAlSi}_{3} \mathrm{O}_{8}+\mathrm{Mg}^{2+}+4 \mathrm{H}_{2} \mathrm{O} \rightarrow 2 \mathrm{Na}^{+}+2 \mathrm{Na}_{0.5} \mathrm{Al}_{1.5} \mathrm{Mg}_{0.5} \mathrm{Si}_{4} \mathrm{O}_{10}(\mathrm{OH})_{2}+\mathrm{H}_{4} \mathrm{SiO}_{4}$ Albite

$\mathrm{Na}-$ Montmorillonite

$\mathrm{NaAlSi}_{3} \mathrm{O}_{8}+\mathrm{CO}_{2}+8 \mathrm{H}_{2} \mathrm{O} \rightarrow \mathrm{Na}^{+}+\mathrm{HCO}_{3}^{-}+\mathrm{Al}(\mathrm{OH})_{3}+3 \mathrm{H}_{4} \mathrm{SiO}_{4}$ Albite Gibbsite

$2 \mathrm{KAlSi}_{3} \mathrm{O}_{8}+2 \mathrm{CO}_{2}+11 \mathrm{H}_{2} \mathrm{O} \rightarrow 2 \mathrm{~K}^{+}+2 \mathrm{HCO}_{3}^{-}+\mathrm{Al}_{2} \mathrm{Si}_{2} \mathrm{O}_{5}(\mathrm{OH})_{4}+4 \mathrm{H}_{4} \mathrm{SiO}_{4}$ Orthoclase (microcline) Kaolinite

The dissolution of anorthite may be a source of $\mathrm{Ca}^{2+}$ also, which takes place by the following reactions (Drever, 1997; Jalali, 2006):

$\mathrm{CaAl}_{2} \mathrm{Si}_{2} \mathrm{O}_{8}+2 \mathrm{CO}_{2}+3 \mathrm{H}_{2} \mathrm{O} \rightarrow \mathrm{Ca}^{2+}+\underset{\mathrm{HCO}_{3}{ }^{-}+\mathrm{Al}_{2} \mathrm{Si}_{2} \mathrm{O}_{5}(\mathrm{OH})_{4}}{\text { Anorthite }}$ Kaolinite

$7 \mathrm{CaAl}_{2} \mathrm{Si}_{2} \mathrm{O}_{8}+12 \mathrm{H}^{+}+8 \mathrm{Si}(\mathrm{OH})_{2} \mathrm{O} \rightarrow 6 \mathrm{Ca}^{2+}+16 \mathrm{H}_{2} \mathrm{O}$

Anorthite

$$
+3 \mathrm{Ca}_{0.33} \mathrm{Al}_{4}\left(\mathrm{Si}_{3.67} \mathrm{Al}_{0.33} \mathrm{O}_{10}\right)_{2}(\mathrm{OH})_{2}
$$

$\mathrm{Ca}-$ Montmorillonite

It is also important to consider reactions with mafic minerals, which are abundant in basalts and andesites. Examples of these reactions follow (Hounslow, 1995; Appelo and Postma, 2005):

$$
\begin{gathered}
2 \mathrm{KMg}_{3} \mathrm{AlSi}_{3} \mathrm{O}_{10}(\mathrm{OH})_{2}+14 \mathrm{CO}_{2}+10 \mathrm{H}_{2} \mathrm{O} \rightarrow \mathrm{Al}_{2} \mathrm{Si}_{2} \mathrm{O}_{5}(\mathrm{OH})_{4}+2 \mathrm{~K}^{+} \\
+6 \mathrm{Mg}^{2+}+14 \mathrm{HCO}_{3}^{-}+2 \mathrm{H}_{4} \mathrm{SiO}_{4} \\
\text { Biotite } \\
\text { Kaolinite }
\end{gathered}
$$

$\mathrm{Mg}_{2} \mathrm{SiO}_{4}+4 \mathrm{CO}_{2}+4 \mathrm{H}_{2} \mathrm{O} \rightarrow 2 \mathrm{Mg}^{2+}+4 \mathrm{HCO}_{3}^{-}+\mathrm{H}_{4} \mathrm{SiO}_{4}$ Forsterite (Olivine)

$$
\begin{aligned}
& \left(\mathrm{Mg}_{0.7} \mathrm{CaAl}_{0.3}\right)\left(\mathrm{Al}_{0.3} \mathrm{Si}_{1.7}\right) \mathrm{O}_{6}+3.4 \mathrm{H}^{+}+1.1 \mathrm{H}_{2} \mathrm{O} \\
& \quad \rightarrow \text { 0. } 3 \mathrm{Al}_{2} \mathrm{Si}_{2} \mathrm{O}_{5}(\mathrm{OH})_{4}+\mathrm{Ca}^{2+}+0.7 \mathrm{Mg}^{2+}+1.1 \mathrm{H}_{4} \mathrm{SiO}_{4}
\end{aligned}
$$$$
\text { Augite }
$$$$
\text { Kaolinite }
$$

The presence of $\mathrm{Fe}$ and $\mathrm{Mn}$ in these aquifers may be due to either natural or anthropogenic sources (Kegley and Andrews, 1998; Senderos, 2001; Ortega-Guerrero, 2009; Corniello and Ducci, 2014). In nature, Fe and Mn are rarely found in elementary state, although several minerals contain varying amounts of these elements, including oxides, sulfides, carbonates and silicates, among others (pyroxenes, amphiboles, biotite, magnetite and in particular, olivine). The reactions involving these minerals can be represented by (Appelo and Postma, 2005; Smith and Roychoudhury, 2013):

$\mathrm{Fe}_{2} \mathrm{SiO}_{4}+4 \mathrm{CO}_{2}+4 \mathrm{H}_{2} \mathrm{O} \rightarrow 2 \mathrm{Fe}^{2+}+4 \mathrm{HCO}_{3}^{-}+\mathrm{H}_{4} \mathrm{SiO}_{4}$ Fayalite (Olivine)

$$
\begin{aligned}
2 \mathrm{~K} & \left(\mathrm{Mg}_{2} \mathrm{Fe}_{2}\right)\left(\mathrm{AlSi}_{3}\right) \mathrm{O}_{10}(\mathrm{OH})_{2}+10 \mathrm{H}^{+}+0.5 \mathrm{O}_{2}+7 \mathrm{H}_{2} \mathrm{O} \\
& \rightarrow \mathrm{Al}_{2} \mathrm{Si}_{2} \mathrm{O}_{5}(\mathrm{OH})_{4}+2 \mathrm{~K}^{+}+4 \mathrm{Mg}^{2+}+2 \mathrm{Fe}(\mathrm{OH})_{3}+4 \mathrm{H}_{4} \mathrm{SiO}_{4}
\end{aligned}
$$

Biotite

$\mathrm{MgFeSi}_{2} \mathrm{O}_{6}+4 \mathrm{H}^{+}+2 \mathrm{H}_{2} \mathrm{O} \rightarrow \mathrm{Fe}^{2+}+\mathrm{Mg}^{2+}+2 \mathrm{H}_{4} \mathrm{SiO}_{4}$ Hypersthene (pyroxene)

Anthropogenic sources of $\mathrm{Fe}$ and $\mathrm{Mn}$ stem from wastewater discharge, dusts and aerosols during metallurgical processing, coal combustion, corrosion of water pumping infrastructure and transport of minerals or contamination associated with mining activities.

Both Mn and Fe may appear in different oxidation states, and thus, the chemistry of these elements in water tends to be very complex; their reduced forms $\left(\mathrm{Fe}^{2+}, \mathrm{Mn}^{2+}\right)$ are more soluble than their oxidized forms $\left(\mathrm{Fe}^{3+}, \mathrm{Mn}^{4+}\right)$. The concentration of $\mathrm{Fe}$ in groundwater may vary widely from 0.5 to $50 \mathrm{mg} \mathrm{L}^{-1}$. Meanwhile, Mn concentration tends to range from values lower than $0.001 \mathrm{mg} \mathrm{L}^{-1}$ to values slightly above $1 \mathrm{mg} \mathrm{L}^{-1}$. Concentration of $\mathrm{Fe}$ tends to be higher since this element is more abundant in the Earth's crust (Appelo and Postma, 2005; BGS, 2003).

The main factors controlling the presence of these elements in water are $\mathrm{pH}$, redox conditions and presence of organic or inorganic ligands (Weng et al., 2007; Smith and Roychoudhury, 2013; Corniello and Ducci, 2014). An acidic pH indicates that both ions are mobile, while a more neutral $\mathrm{pH}$ indicates that mobility is determined by redox conditions. Likewise, under oxidizing conditions, concentrations of both $\mathrm{Fe}$ and $\mathrm{Mn}$ are low, as these elements tend to appear as insoluble oxides; under reducing conditions, both elements become more soluble (Appelo and Postma, 2005; Weng et al., 2007). Another influencing factor is the pumping of water from wells, which causes changes in pressure and promotes intake of oxygen by aeration. This may lead to the precipitation of insoluble Fe and Mn hydroxides (Kazak and Pozdniakov, 2010), and thus, to a decrease in well efficiency (Senderos, 2001).

In water for human use and consumption, high concentrations of $\mathrm{Fe}$ or Mn deteriorate supply system infrastructure, lead to the appearance of stains on clothing, sanitary and domestic utensils, modify organoleptic characteristics and lead to biofouling and microbiological corrosion (Kegley and Andrews, 1998; Smith and Roychoudhury, 2013). In addition, the potentially toxic effects of Fe and Mn pose risks to human health, where for example, excess ingestion of Fe can provoke anatomical and functional alterations, especially in the liver, pancreas, heart and pituitary gland. Prolonged contact with Fe may produce conjunctivitis, chorioretinitis, retinitis and siderosis; meanwhile, high levels of Mn may alter the nervous system, irritate lungs and cause pneumonia (NRC US, 1979; BGS, 2003; Álvarez-Bastida et al., 2013).

Given the risks to human health associated with excessive $\mathrm{Fe}$ and Mn consumption, the Mexican regulatory framework (NOM-127-SSA11994, 2000) recommends that concentrations of $\mathrm{Fe}$ and $\mathrm{Mn}$ do not surpass $0.30 \mathrm{mg} \mathrm{L}^{-1}$ and $0.15 \mathrm{mg} \mathrm{L}^{-1}$, respectively. In the United States, the EPA $(2003,2004)$ outlines upper limits of $0.30 \mathrm{mg} \mathrm{L}^{-1}$ for Fe and $0.05 \mathrm{mg} \mathrm{L}^{-1}$ for $\mathrm{Mn}$.

One example of this problem occurs in the water of the Tenancingo Valley aquifer (Mexico). The National Water Commission (Comisión Nacional de Agua; CNA, 2001) reports high concentrations of Fe, Mn, and $\mathrm{NO}_{3}{ }^{-}$in the aquifer, and water from several wells receive purification treatments due to presence of Fe and Mn.

Previous studies performed on the Tenancingo Valley aquifer have not achieved conclusive results regarding the origin of $\mathrm{Fe}$ and $\mathrm{Mn}$, nor have hydrogeochemical evaluations of the aquifer been performed (CNA, 2001; Medina, 2011). Furthermore, the aquifer could be subjected to a more intense exploitation in the future and at a certain point, anthropogenic contaminants that are currently retained in the unsaturated zone may begin to appear in groundwater.

Thus, the objectives of this study on the Tenancingo Valley aquifer are to: 1) identify the hydrogeochemical processes that control the chemical composition of the groundwater, 2) perform a study to explain the behavior of $\mathrm{Fe}$ and $\mathrm{Mn}$, their origin and the geological processes that determine their presence, and 3) evaluate the groundwater use for human consumption and irrigation.

\section{Study area}

Located in the central region of the Mexican Republic, the study area lies $48 \mathrm{~km}$ south of Toluca, the capital of the State of Mexico (Fig. 1). The elevation ranges from 2060 to $2490 \mathrm{~m}$ asl; the climate is temperate, according to the Köppen climate classification, with an average temperature of $19.6{ }^{\circ} \mathrm{C}$ and an average rainfall of $1050 \mathrm{~mm}$ (GEM, 1997). The Tenancingo River is the main river and flows perennially through the central valley, although high levels of contamination are present due to dumping of wastewater (CONAGUA, 2007).

Volcanic and sedimentary processes determine the geology of the area (Fig. 1). Volcanic activity produced andesite material (Tmpz), basalt lava and breccia (Qb), lahars and tuffs (Tpch), and sedimentary 


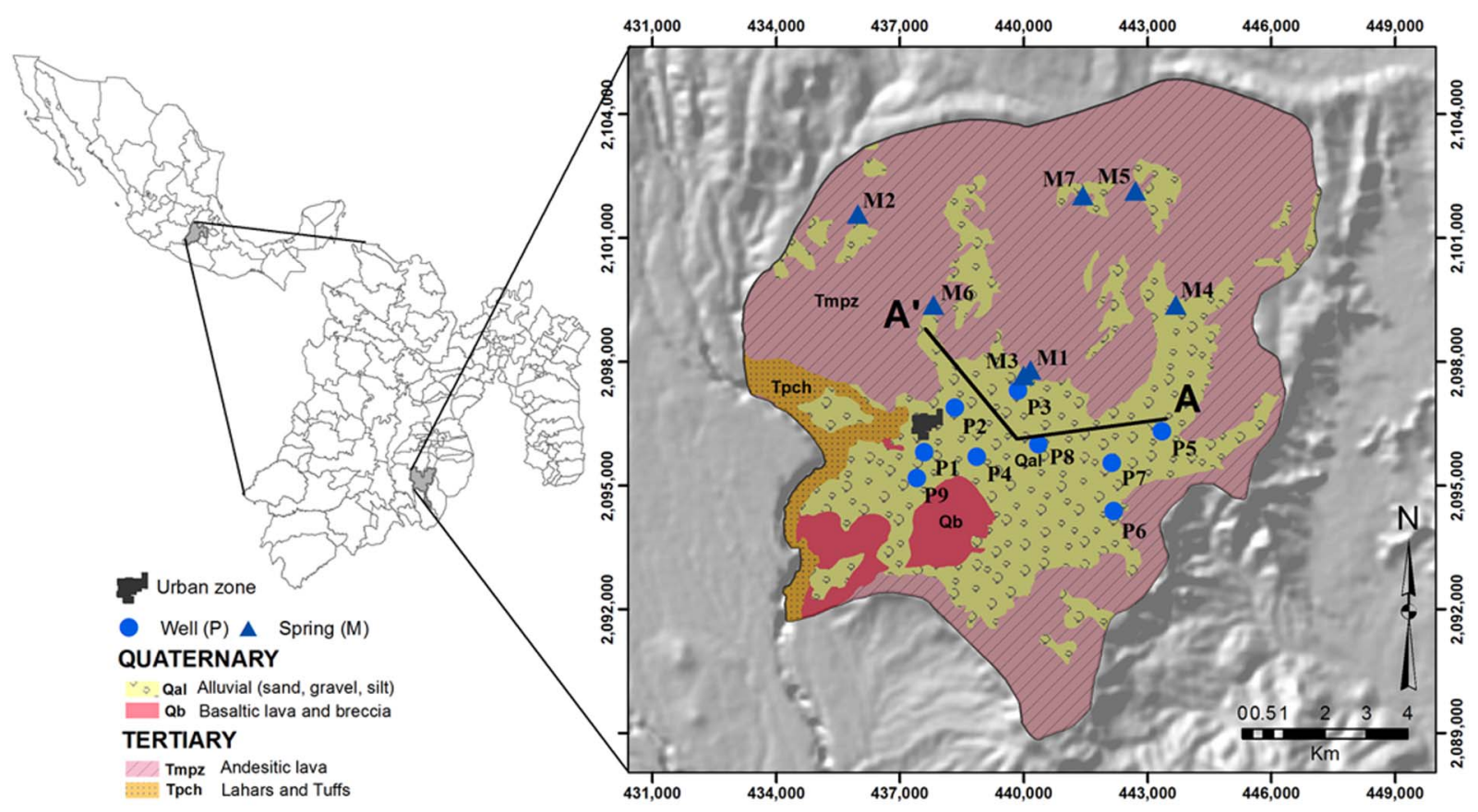

Fig. 1. Map of the study area showing the location in respect to Mexico and base map with geology and sampling locations.

processes originated alluvial deposits (Qal). Of these materials, andesites and alluvial deposits are of the greatest hydrogeological interest, as these materials have formed the aquifer units currently under exploitation (CNA, 2001).

In the western portion of the study area, a Tpch formation with a surface area of $5.2 \mathrm{~km}^{2}$ is exclusively composed of fragments derived from volcanic rocks and intercalated with lahars, although wells are not present. Qb deposits are distributed along the central-western portion of the valley and to the west of the study area in the form of small stretches or outflow channels enclosed by cliffs or valleys, including self-brecciated and block formations. A formation of pyroclastic material spans $6.4 \mathrm{~km}^{2}$, varying in texture from lapilli (very permeable) to ash. Lithologically, this unit is constituted by dense basalt with grey to dark grey olivine and pyroxene material, although breccia and block agglomerates and reddish tezontle volcanic rock may be observed.

The Tmpz formation is distributed along the northern, eastern and southern peripheries of the valley, composed of grey andesites containing mainly plagioclases and mafic minerals characterized by augite and hypersthene phenocrysts, although hornblende and biotite are also present. Occasional volcanic or lahar deposits are intercalated throughout this formation, which is estimated to reach an approximate thickness of $500 \mathrm{~m}$ and occupy an extension of $83.6 \mathrm{~km}^{2}$ in the study area. Low permeability values are presented in this formation (Medina, 2011).

Thickness of andesite materials is variable, horizontal and vertical hydraulic conductivity average at $0.02 \mathrm{~m} \mathrm{~d}^{-1}$. Specific yield is 0.01 , and a total porosity is $0.17 \%$ (Medina, 2011). Localized water use across the Tmpz formation stems from springs, and dug wells with a maximum depth of $15 \mathrm{~m}$, and is characterized by low rates of water flow for extraction purposes.

The largest recharge zone of the aquifer is composed of detritic materials consisting of fragments derived from volcanic rocks (Qal). This area is the most exploited due to its hydraulic potential as an unconfined aquifer. The horizontal hydraulic conductivity averages at $4 \mathrm{~m} \mathrm{~d}^{-1}$ and the vertical hydraulic conductivity at $0.4 \mathrm{~m} \mathrm{~d}^{-1}$, with a specific yield of 0.15 and a total porosity of $0.3 \%$ (Medina, 2011). Depths of boreholes in Qal range from 180 to $240 \mathrm{~m}$, with extraction volumes of $0.5 \mathrm{~L} \mathrm{~s}^{-1}$ to $35 \mathrm{~L} \mathrm{~s}^{-1}$.

In the aquifer, groundwater flows from the northern, eastern and southern peripheries towards the central portion of the study area, and from there, converges towards the west, following the course of the Tenancingo River. The depth of the groundwater table level varies between a minimum of $1.5 \mathrm{~m}$ and maximum of $80 \mathrm{~m}$.

Although the degree of exploitation of this detritic aquifer continues to increase, it may be considered underexploited since the availability of groundwater is $3.8 \mathrm{Mm}^{3}$ year $^{-1}$, based on a recharge of $8.6 \mathrm{Mm}^{3}$ year $^{-1}$ and an extraction volume of $4.8 \mathrm{Mm}^{3}$ year $^{-1}$ (CONAGUA, 2007). Yet in the central valley groundwater level depressions (38-80 $\mathrm{m}$ of depth) have occurred due to the concentration of water pumping in this area (several pump water for urban supply $24 \mathrm{~h}$ a day).

No data are available on variations in the withdrawal flow but on some chemical characteristics of the water. The chemical characteristics allow verifying how from the year 2001 there has been an increase in the concentration of TDS and chlorides. In 2001, the values of TDS in the wells located in the zone of greater pumping were around $700 \mathrm{mg} \mathrm{L}^{-1}$, and in 2010 in $1000 \mathrm{mg} \mathrm{L}^{-1}$; while the chloride concentration increased from 100 to $300 \mathrm{mg} \mathrm{L}^{-1}$. As for Fe and $\mathrm{Mn}$, concentrations have varied between 1 and $7 \mathrm{mg} \mathrm{L}^{-1}$ for $\mathrm{Fe}$ and between 0.05 and 0.40 for Mn (GEM 2001-2011).

In the area, the main economic activity is agriculture and in particular, floriculture, which is destined for regional and national trade and exportation. Due to the economic success of this activity, an accelerated population growth has occurred, leading to an increase in the use of agrochemicals and in waste at dumpsites. This has led to a diversification in the volume and type of contaminants that may be exposed to groundwater (Medina, 2011; CNA, 2001).

\section{Materials and methods}

\subsection{Water sampling}

A sampling network of 9 wells (boreholes) and 7 springs was established (Fig. 1, Table 1), to sample according to the following three motives: 1) sample all active wells in the study area, 2) select natural springs distributed throughout the study area, and 3) consider possible restrictions in access to sites due to sampling techniques.

Two periods of sampling were carried out at the end of the dry (June 
Table 1

General data of the wells and springs (CAEM, 2012; Medina, 2011).

\begin{tabular}{|c|c|c|c|c|c|c|c|}
\hline ID & $\begin{array}{l}\text { Depth of SL (m) } \\
* 2011 \\
* * 2012\end{array}$ & $\begin{array}{l}\text { Depth of DL (m) } \\
* 2011 \\
* * 2012\end{array}$ & $\begin{array}{l}\mathrm{Q}\left(\mathrm{m}^{3} / \mathrm{d}\right) \\
* 2011 \\
* * 2012\end{array}$ & Well depth (m bgl) & Depth of open section (m bgl) & Geology & Water use \\
\hline $\mathrm{P} 1$ & $* 33$ & *64 & *4752 & 160 & $56-156$ & Qal & Drinking water \\
\hline $\mathrm{P} 2$ & $* 38$ & *59 & $* 4320$ & 150 & $50-120$ & Qal & Drinking water \\
\hline P3 & *6 & *15 & *3456 & 220 & $98-200$ & Qal & Drinking water \\
\hline P4 & $* 38$ & *68 & $* 2870$ & 200 & $110-181$ & Qal & Drinking water \\
\hline P5 & $* * 50$ & $* * 143$ & $* * 319$ & 200 & ND & Qal & Drinking water \\
\hline P6 & $* * 25$ & $* * 34$ & $* * 1209$ & 200 & ND & Qal-Tmpz & Drinking water \\
\hline P7 & $* * 30$ & $* * 55$ & $* * 1296$ & 200 & ND & Qal & Drinking water \\
\hline P8 & ND & ND & ND & 100 & ND & Qal & Drinking water \\
\hline P9 & $* * 33$ & $* * 50$ & $* * 345$ & 60 & ND & Qal-Qb & Livestock \\
\hline M1 & NA & NA & SD & NA & NA & Tmpz-Qal & Drinking water/agricultural \\
\hline M2 & NA & NA & $* * 993$ & NA & NA & Tmpz & Drinking water/agricultural \\
\hline M3 & NA & NA & $* * 138$ & NA & NA & Tmpz-Qal & Drinking water/agricultural \\
\hline M4 & NA & NA & $* * 52$ & NA & NA & Tmpz-Qal & Drinking water/agricultural \\
\hline M5 & NA & NA & $* * 268$ & NA & NA & Tmpz & Drinking water/agricultural \\
\hline M6 & NA & NA & ND & NA & NA & Tmpz & Drinking water/agricultural \\
\hline M7 & NA & NA & $* * 147$ & NA & NA & Tmpz & Drinking water/agricultural \\
\hline
\end{tabular}

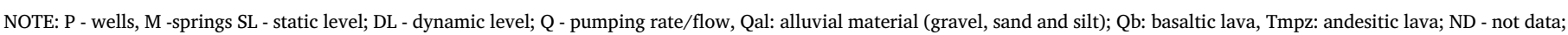
NA - not applicable.

2012) and rainy (November 2012) seasons. Containers, use of preservatives and care during storage and transport to laboratory were in conformity with the guidelines specified by APHA-AWWA-WFPC (2005).

During each sampling session, 16 water samples (one per site) were obtained, in addition to a duplicate set. Wells not currently in operation were purged for $10 \mathrm{~min}$ before sampling. For springs, samples were obtained by submerging the sampling container in an open-air artificial reservoir, with sufficient flow to ensure sample integrity.

\subsection{Field and laboratory measurements}

In situ, $\mathrm{pH}$, temperature $\left(\mathrm{T}^{\mathrm{e}}\right)$, electrical conductivity (EC), redox potential (Eh) and alkalinity were evaluated. The $\mathrm{pH}, \mathrm{T}^{\mathrm{e}}, \mathrm{EC}$, and $\mathrm{Eh}$ were determined with a Thermo Scientific meter. Alkalinity was measured by titration with commercial equipment (La Motte, code 3467). TDS was calculated from summation of ion concentrations.

$250 \mathrm{~mL}$ of water destined for cation analysis were filtered in situ through a nitrocellulose membrane (Millipore, $0.45 \mu \mathrm{m}$ mesh) and acidified with reagent grade $\mathrm{HNO}_{3}$ until reaching $\mathrm{pH}<2$. The volume of the water sample for anion analysis was $1000 \mathrm{~mL}$. All water samples for evaluation of ionic content were preserved in ice until arriving at the laboratory for analysis.

Cation analysis was performed by the inductively coupled plasmamass spectrometry technique (ICP-MS) at the Laboratory of Environmental Geochemistry of Autonomous National University Mexico-Campus Juriquilla. Sulfate content was determined by the turbidimetric method; chloride by titration with silver nitrate; nitrate by the brucine sulfate method and ammonium and nitrite with the $\mathrm{HACH}$ field-sampling kit. These chemical determinations were done at the Laboratory of Water Quality of CIRA.

In the first sampling campaign, the most representative chemical parameters were considered, which were: $\mathrm{Ca}^{2+}, \mathrm{K}^{+}, \mathrm{Mg}^{2+}, \mathrm{Na}^{+}, \mathrm{Mn}$, $\mathrm{Fe}, \mathrm{Cl}^{-}, \mathrm{NO}_{3}{ }^{-}$, and $\mathrm{SO}_{4}{ }^{2-}$. In the second session, was also included: $\mathrm{Si}$, $\mathrm{Al}, \mathrm{NO}_{2}{ }^{-}$and $\mathrm{NH}_{4}{ }^{+}$. For the other analyzed elements during the sample campaigns, such as $\mathrm{As}, \mathrm{Be}, \mathrm{Bi}, \mathrm{Cd}, \mathrm{Cr}, \mathrm{Cu}, \mathrm{Li}, \mathrm{Mo}, \mathrm{Pb}, \mathrm{Sb}, \mathrm{Se}, \mathrm{Sr}, \mathrm{V}$ and $\mathrm{Zn}$; their concentrations were under or close to the detection limit for the analytical method used (ICP-MS).

The concentration of carbonate $\left(\mathrm{CO}_{3}{ }^{2-}\right)$ and bicarbonate ions $\left(\mathrm{HCO}_{3}{ }^{-}\right)$was calculated, using the following formulas (Deutsch, 1997):
$\mathrm{CO}_{3}^{2-}\left(\mathrm{mg} \mathrm{L}^{-1}\right)=\frac{\text { Alkalinity }\left(\mathrm{mg} \mathrm{L}^{-1} \mathrm{CaCO}_{3}\right)}{\left(2+\frac{10^{-\mathrm{pH}}}{10^{-10.3}}\right) * 50} * 60$

$\mathrm{HCO}_{3}^{-}\left(\mathrm{mg} \mathrm{L}^{-1}\right)=\frac{\text { Alkalinity }\left(\mathrm{mg} \mathrm{L}^{-1} \mathrm{CaCO}_{3}\right)}{\left(1+\frac{2 \cdot 10^{-10.3}}{10^{-\mathrm{pH}}}\right) * 50} * 61$

A charge balance verified the results for ionic content of water. Charge balance errors were less $8 \%$, except for water samples P6, P9, M2 and M7 with errors between 9 and 10\%. The error was considered acceptable due to the low mineralization of the water (EC $<250 \mu \mathrm{S}$ / cm) (Koh et al., 2009).

\subsection{Data analysis}

The hydrogeochemical characterization was performed using graphical and statistical tools in the AquaChem 3.7 software (Waterloo Hydrogeologic Inc., 1999).

To evaluate the solubility of $\mathrm{Fe}$ and $\mathrm{Mn}$ in groundwater, $\mathrm{pH} / \mathrm{Eh}$ diagrams were used, also known as speciation or Pourbaix diagrams. Several $\mathrm{pH} / \mathrm{Eh}$ diagrams exist for iron and manganese, including the $\mathrm{Fe}$ $\mathrm{O}-\mathrm{H}$ diagram, which is widely used for being easy to understand and having clearly defined fields. From this diagram, others are also derived as a function of the carbon, silica or sulfur content, as well as the mineralogical stability (Appelo and Postma, 2005). These diagrams were developed using the Hydra-Medusa software (Puigdomenech, 2004).

An Anderson-Darling test was test to check if the data is normally distributed. The results obtained show values of $p \leq 0.05$. Only Eh have values of $\mathrm{p}=0.14$. The correlation matrix was calculated considering that data are non-parametric. The matrix calculation was performed with the Spearman rho coefficient with a $\mathrm{p}<0.05$. Parameters with few data were not used $\left(\mathrm{NO}_{3}{ }^{-}, \mathrm{NH}_{4}{ }^{+}, \mathrm{NO}_{2}{ }^{-}\right)$. In the case of samples that presented values below the quantification limit, this limit value was used as data. The MINITAB software was used for all calculations.

This coefficient is a statistical measure of the strength of a relationship between paired data. It can describe the strength of the correlation using the guide that Koh et al. (2009) suggest for the absolute value of $r$ : If the $r$ is $>0.7$, two parameters are considered to be strong correlated, whereas if the value $r$ is between 0.5 and 0.7 , it indicates a moderate correlation at a significance level $\mathrm{p}=0.05$.

The saturation index (SI) and ion speciation were calculated using 
PHREEQC-Version 3 (Parkhurst and Appelo, 2013). The SI is a measure of the departure from equilibrium of the water with respect to mineral phases. A SI value of zero, with an associated range of uncertainty ( \pm 0.1 ), indicates the water is in equilibrium with respect to the mineral phase; a value of less than zero indicates undersaturation (mineral dissolution is possible); and a value greater than zero indicates oversaturation (mineral precipitation is possible) (Appelo and Postma, 2005). These calculations assume that the dissolved species in the groundwater are at chemical equilibrium.

\subsection{Human consumption and irrigation quality}

Water quality for human consumption was determined by comparing the values of the studied parameters with the values specified by Mexican legislative regulations (NOM-127-SSA1-1994, 2000). The suitability of water for use in agricultural activities was evaluated with the support of Wilcox and US Salinity Laboratory diagrams (Wilcox, 1955; USSL, 1954).

\section{Results and discussion}

\subsection{General physicochemical characteristics}

In Tables 2 and 3, the studied physicochemical characteristics for the dry and rainy sampling periods are presented, respectively. For water sampled in wells, overall $\mathrm{pH}$ ranged from neutral to slightly alkaline, except in wells P1 and P2, which had a slightly acidic pH (6.53-6.75). These wells are located within an urban area (Fig. 1) and are exploited $24 \mathrm{~h}$ a day. Meanwhile, $\mathrm{pH}$ values $>8.3$ were observed in wells P4, P6 and P9, and for these samples, the concentration of carbonate ions $\left(\mathrm{CO}_{3}{ }^{2-}\right)$ was calculated. Based on these calculations, in dry season at wells $\mathrm{P} 4$ and $\mathrm{P} 6, \mathrm{CO}_{3}{ }^{2-}$ content was 1.80 and $2.60 \mathrm{mg} \mathrm{L}^{-1}$, respectively, and $2.24 \mathrm{mg} \mathrm{L}^{-1}$ during rainy reason in $\mathrm{P} 9$. In the case of springs (Tables 2 and 3), $\mathrm{pH}$ values (7.10-7.81) tend to be lower in comparison to the majority of wells. These lower values may be explained by the intake of $\mathrm{CO}_{2}$ from the atmosphere as well as its presence in soil due to root respiration and degradation of organic matter (Appelo and Postma, 2005). Seasonal variation in $\mathrm{pH}$ values was minimal.
The EC values in groundwater fluctuated between 137 and $793 \mu \mathrm{cm}^{-1}$ in the dry season and between 124 and $780 \mu \mathrm{Sm}^{-1}$ in the rainy season (Tables 2 and 3). After a rainy period (recharge), a slight decrease in EC is observed, which was likely due to a dilution effect, with the exception of wells P1 and P2. These wells presented the highest values for EC in both sampling periods $\left(677-793 \mu \mathrm{S} \mathrm{cm}^{-1}\right)$.

For springs, the highest EC was observed in M7 $\left(229-232 \mu \mathrm{S} \mathrm{cm}^{-1}\right)$, which also has the highest $\mathrm{NO}_{3}{ }^{-}$content $\left(46.0 \mathrm{mg} \mathrm{L}^{-1}\right.$ during dry season and $12.5 \mathrm{mg} \mathrm{L}^{-1}$ during rainy season). Presence of $\mathrm{NO}_{3}{ }^{-}$would also indicate a process of leaching from the soil surface, transferring contaminants to groundwater.

With respect to Eh, a large variability was found between sampling periods. In the dry season, the extreme values were -220 and $282 \mathrm{mV}$, and in the rainy season, -208.1 and $327 \mathrm{mV}$ (Tables 2 and 3). This suggests that the groundwater environment is both oxidizing and reducing (Kazak and Pozdniakov, 2010).

Bicarbonate concentration in samples proceeding from wells did not exceed $156 \mathrm{mg} \mathrm{L}^{-1}$ in the dry season or $219 \mathrm{mg} \mathrm{L}^{-1}$ in the rainy season, with the exception of wells P1 and P2, which had concentrations between 263 and $424 \mathrm{mg} \mathrm{L}^{-1}$. In springs, concentration of bicarbonates did not surpass $156 \mathrm{mg} \mathrm{L}^{-1}$ in the dry season and $151 \mathrm{mg} \mathrm{L}^{-1}$ in the rainy season, including minimum values close to $70 \mathrm{mg} \mathrm{L}^{-1}$ during both seasons.

Chloride content was low in both wells and natural springs and did not exceed $19 \mathrm{mg} \mathrm{L}^{-1}$, except in P1, P2 and M7, where maximum values of 96,89 and $26 \mathrm{mg} \mathrm{L}^{-1}$ were found. Low values for chloride content in nearly all of the sampled points may be associated with the rapid passage of water through the aquifer, which is characteristic of aquifers with a local flow; meanwhile, higher values for chloride (as well as those of other ions) could be associated with an intermediate flow (Tóth, 1999). In the case of natural spring M7, the influence of evapotranspiration and contamination may be present (e.g. chloride and nitrate), resulting in a higher ionic content.

The sulfate was detected in both springs and wells, although several samples were below the quantifiable limit of $5 \mathrm{mg} \mathrm{L}^{-1}$. In wells, the highest value was $18 \mathrm{mg} \mathrm{L}^{-1}$ at $\mathrm{P} 8$, and in springs, concentrations neared $26 \mathrm{mg} \mathrm{L}^{-1}$, with the highest concentration at M7. In the case of this anion, the influence of redox conditions in the aquifer should be taken into consideration upon determining the sulfur species that may

Table 2

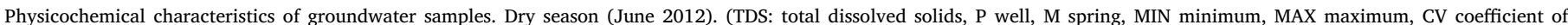
variation, SD standard deviation, ql quantification limit, $\mathrm{ql} \mathrm{Fe}=0.0043 \mathrm{mg} \mathrm{L}^{-1}, \mathrm{ql} \mathrm{Mn}=0.0003 \mathrm{mg} \mathrm{L}^{-1}$ ).

\begin{tabular}{|c|c|c|c|c|c|c|c|c|c|c|c|c|c|c|c|}
\hline & $\mathrm{pH}$ & Tw & Eh & EC & TDS & $\mathrm{Ca}^{2+}$ & $\mathrm{K}^{+}$ & $\mathrm{Mg}^{2+}$ & $\mathrm{Na}^{+}$ & $\mathrm{HCO}_{3}{ }^{-}$ & $\mathrm{SO}_{4}{ }^{2-}$ & $\mathrm{Cl}^{-}$ & $\mathrm{Fe}$ & Mn & $\mathrm{NO}_{3}{ }^{-}$ \\
\hline & & ${ }^{\circ} \mathrm{C}$ & $\mathrm{mV}$ & $\mu \mathrm{S} / \mathrm{cm}$ & \multicolumn{11}{|c|}{$\mathrm{mg} / \mathrm{L}^{-1}$} \\
\hline P1 & 6.75 & 19.5 & 281.5 & 677.0 & 535 & 34.40 & 8.93 & 17.70 & 84.03 & 283 & $<5.00$ & 96.58 & 0.19 & 0.01 & 5.04 \\
\hline P2 & 6.63 & 20.4 & -99.4 & 793.0 & 672 & 36.57 & 7.35 & 22.97 & 85.72 & 424 & 7.26 & 83.05 & 4.18 & 0.22 & 0.22 \\
\hline P3 & 8.06 & 17.4 & 3.5 & 198.4 & 211 & 11.79 & 3.12 & 13.73 & 14.59 & 140 & $<5.00$ & 18.41 & 0.03 & $<\mathrm{ql}$ & 4.02 \\
\hline P4 & 8.38 & 20.2 & -151.1 & 212.8 & 223 & 12.13 & 3.06 & 14.27 & 16.17 & 152 & $<5.00$ & 18.41 & 0.36 & 0.06 & 1.06 \\
\hline P5 & 8.02 & 19.5 & 88.9 & 222.5 & 234 & 12.39 & 5.21 & 13.09 & 19.10 & 157 & 6.43 & 19.92 & 0.64 & 0.18 & 0.22 \\
\hline P6 & 8.53 & 24.9 & 161.0 & 217.2 & 226 & 11.93 & 3.95 & 11.63 & 19.18 & 156 & $<5.00$ & 16.16 & 0.02 & $<\mathrm{ql}$ & 2.30 \\
\hline P7 & 7.35 & 20.6 & -185.8 & 210.6 & 235 & 14.02 & 6.47 & 9.82 & 18.03 & 156 & 7.74 & 19.92 & 2.46 & 0.56 & 0.31 \\
\hline P8 & 7.29 & 19.2 & -219.7 & 171.6 & 201 & 14.47 & 5.33 & 9.21 & 11.91 & 132 & 13.34 & 10.52 & 2.32 & 0.36 & 1.94 \\
\hline P9 & 7.82 & 20.0 & 230.4 & 205.6 & 212 & 13.93 & 3.18 & 12.94 & 10.89 & 155 & $<5.00$ & 9.02 & $<\mathrm{ql}$ & $<\mathrm{ql}$ & 1.55 \\
\hline M1 & 7.59 & 17.2 & 29.8 & 183.1 & 197 & 11.48 & 2.92 & 12.79 & 13.55 & 128 & 7.66 & 16.53 & 0.02 & 0.01 & 4.37 \\
\hline M2 & 7.10 & 15.5 & 50.9 & 137.4 & 179 & 8.69 & 2.57 & 9.44 & 13.57 & 117 & $<5.00$ & 17.66 & 0.02 & $<\mathrm{ql}$ & 4.77 \\
\hline M3 & 7.36 & 16.5 & 268.0 & 222.8 & 227 & 12.56 & 3.39 & 15.01 & 16.87 & 156 & $<5.00$ & 15.03 & 0.02 & 0.01 & 3.49 \\
\hline M4 & 7.63 & 17.4 & 245.8 & 159.2 & 173 & 8.34 & 6.03 & 11.65 & 10.42 & 115 & $<5.00$ & 13.53 & $<\mathrm{ql}$ & 0.01 & 2.96 \\
\hline M5 & 7.25 & 16.0 & 156.9 & 185.4 & 163 & 13.87 & 3.47 & 11.28 & 11.89 & 93 & 8.46 & 12.78 & $<\mathrm{ql}$ & 0.01 & 8.88 \\
\hline M6 & 7.81 & 16.2 & 257.0 & 175.6 & 193 & 12.00 & 3.15 & 12.64 & 14.08 & 127 & $<5.00$ & 15.41 & 0.01 & 0.01 & 3.36 \\
\hline M7 & 7.33 & 16.3 & 202.0 & 229.5 & 201 & 24.71 & 3.38 & 11.78 & 10.62 & 65 & 13.92 & 25.55 & 0.03 & 0.07 & 46.28 \\
\hline MÍN & 6.63 & 15.50 & -219.7 & 137.40 & 163 & 8.34 & 2.57 & 9.21 & 10.42 & 65 & 6.43 & 9.02 & 0.01 & 0.01 & 0.22 \\
\hline MÁX & 8.53 & 24.90 & 281.50 & 793.00 & 672 & 36.57 & 8.93 & 22.97 & 85.72 & 424 & 13.92 & 96.58 & 4.18 & 0.56 & 46.28 \\
\hline AVERAGE & 7.56 & 18.55 & 82.48 & 262.61 & 234 & 15.83 & 4.47 & 13.12 & 23.16 & 160 & 9.26 & 25.53 & 0.74 & 0.1 & 5.67 \\
\hline C.V. & 0.07 & 0.13 & 2.08 & 0.71 & 2,5 & 0.53 & 0.42 & 0.26 & 1.05 & 0.52 & 0.33 & 1.00 & 1.76 & 1.67 & 1.95 \\
\hline S.D. & 0.53 & 2.45 & 171.27 & 187.34 & 140 & 8.46 & 1.88 & 3.40 & 24.26 & 83.45 & 3.05 & 25.52 & 1.30 & 0.16 & 11.06 \\
\hline
\end{tabular}


Table 3

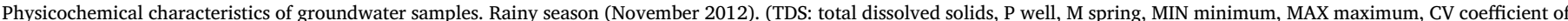

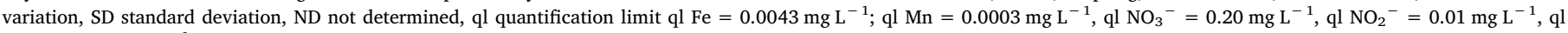
$\mathrm{NH}_{4}^{+}=0.01 \mathrm{mg} \mathrm{L}^{-1}$ ).

\begin{tabular}{|c|c|c|c|c|c|c|c|c|c|c|c|c|c|c|c|c|c|c|c|}
\hline & $\mathrm{pH}$ & $\mathrm{Tw}$ & Eh & $\mathrm{EC}$ & TDS & $\mathrm{Ca}^{2+}$ & $\mathrm{K}^{+}$ & $\mathrm{Mg}^{2+}$ & $\mathrm{Na}^{+}$ & $\mathrm{HCO}_{3}{ }^{-}$ & $\mathrm{SO}_{4}{ }^{2-}$ & $\mathrm{Cl}^{-}$ & $\mathrm{Fe}$ & $\mathrm{Mn}$ & $\mathrm{NO}_{3}^{-}$ & $\mathrm{NO}_{2}^{-}$ & $\mathrm{NH}_{4}^{+}$ & $\mathrm{Si}$ & $\mathrm{Al}$ \\
\hline & & ${ }^{\circ} \mathrm{C}$ & $\mathrm{mV}$ & $\mu \mathrm{S} / \mathrm{cm}$ & \multicolumn{15}{|c|}{$\mathrm{mg} \mathrm{L}^{-1}$} \\
\hline P1 & 6.64 & 19.2 & 188.5 & 686.0 & 550 & 31.98 & 8.95 & 18.11 & 89.57 & 263.4 & 7.13 & 93.85 & 0.14 & 0.01 & 2.47 & $<\mathrm{ql}$ & 0.05 & 34.8 & 0.005 \\
\hline P2 & 6.53 & 21.0 & -112.4 & 780.0 & 677 & 35.29 & 7.45 & 23.75 & 89.18 & 387.8 & 7.69 & 73.96 & 4.12 & 0.26 & $<\mathrm{ql}$ & $<\mathrm{ql}$ & 0.06 & 47.6 & 0.007 \\
\hline P3 & 7.43 & 17.6 & 78.0 & 192.9 & 237 & 11.52 & 2.98 & 13.64 & 15.10 & 150.9 & $<5.00$ & 11.24 & 0.03 & 0.01 & 3.23 & $<\mathrm{ql}$ & ND & 28.6 & 0.011 \\
\hline P4 & 7.58 & 18.8 & -93.3 & 207.4 & 266 & 11.46 & 3.02 & 15.11 & 16.90 & 170.0 & $<5.00$ & 12.97 & 0.39 & 0.07 & 0.49 & $<\mathrm{ql}$ & 0.10 & 35.3 & 0.001 \\
\hline P5 & 7.56 & 20.8 & -208.1 & 213.5 & 270 & 11.40 & 5.05 & 13.20 & 19.65 & 162.9 & 8.68 & 12.97 & 0.12 & 0.19 & 0.22 & 0.05 & 0.20 & 35.3 & 0.018 \\
\hline P6 & 7.90 & 19.7 & 74.4 & 195.8 & 258 & 11.29 & 4.17 & 12.41 & 21.13 & 169.5 & $<5.00$ & 9.95 & 0.02 & 0.01 & 1.06 & $<\mathrm{ql}$ & ND & 28.3 & 0.005 \\
\hline P7 & 7.45 & 19.0 & -327.0 & 215.8 & 289 & 13.24 & 7.06 & 11.40 & 24.58 & 185.0 & 7.71 & 12.11 & 0.51 & 0.45 & $<\mathrm{ql}$ & $<\mathrm{ql}$ & 0.98 & 27.2 & 0.009 \\
\hline P8 & 6.50 & 22.0 & -200.0 & 192.0 & 259 & 14.79 & 4.98 & 10.19 & 12.85 & 156.1 & 13.59 & 9.08 & 1.93 & 0.38 & $<\mathrm{ql}$ & $<\mathrm{ql}$ & 0.52 & 35.0 & 0.003 \\
\hline P9 & 8.49 & 16.0 & 25.6 & 175.7 & 227 & 12.72 & 3.25 & 13.51 & 11.66 & 146.7 & $<5.00$ & 11.24 & $<\mathrm{ql}$ & $<\mathrm{ql}$ & 3.14 & $<\mathrm{ql}$ & ND & 25.2 & 0.005 \\
\hline M1 & 7.32 & 18.8 & 277.3 & 185.6 & 246 & 11.09 & 3.00 & 13.58 & 14.26 & 151.0 & 8.86 & 12.97 & 0.03 & 0.01 & 1.63 & 0.03 & ND & 29.8 & 0.028 \\
\hline M2 & 7.45 & 14.5 & 68.1 & 124.9 & 204 & 8.35 & 2.39 & 9.43 & 14.93 & 120.0 & $<5.00$ & 12.97 & 0.02 & $<\mathrm{ql}$ & 1.77 & $<\mathrm{ql}$ & ND & 29.6 & 0.006 \\
\hline M3 & 7.46 & 17.1 & 95.1 & 213.6 & 267 & 12.37 & 3.19 & 15.67 & 16.36 & 164.2 & 7.64 & 14.27 & 0.01 & $<\mathrm{ql}$ & 1.46 & $<\mathrm{ql}$ & ND & 31.9 & 0.064 \\
\hline M4 & 7.41 & 16.0 & 40.8 & 151.1 & 207 & 8.67 & 3.09 & 12.69 & 12.57 & 126.6 & $<5.00$ & 10.38 & 0.02 & $<\mathrm{ql}$ & $<\mathrm{ql}$ & $<\mathrm{ql}$ & ND & 32.7 & 0.006 \\
\hline M5 & 7.41 & 16.0 & 100.3 & 164.1 & 206 & 13.76 & 2.80 & 12.23 & 11.60 & 114.4 & 9.90 & 13.41 & 0.01 & $<\mathrm{ql}$ & 3.54 & $<\mathrm{ql}$ & ND & 24.2 & 0.010 \\
\hline M6 & 7.46 & 16.5 & 1.5 & 166.8 & 220 & 11.09 & 3.06 & 12.94 & 12.72 & 143.5 & $<5.00$ & 11.24 & 0.02 & $<\mathrm{ql}$ & 1.55 & $<\mathrm{ql}$ & ND & 24.1 & 0.013 \\
\hline M7 & 7.28 & 16.0 & 45.4 & 232.2 & 200 & 24.29 & 3.98 & 12.24 & 10.77 & 83.1 & 13.92 & 26.38 & 0.09 & 0.09 & 12.55 & 0.02 & ND & 12.5 & 0.008 \\
\hline MÍN & 6.50 & 14.5 & -208.1 & 124.9 & 190 & 8.35 & 2.39 & 9.43 & 10.77 & 83.1 & 7.13 & 9.08 & 0.01 & 0.01 & 0.22 & 0.02 & 0.05 & 12.5 & 0.001 \\
\hline MÁX & 8.49 & 22.0 & 327.0 & 780.0 & 677 & 35.29 & 8.95 & 23.75 & 89.57 & 387.8 & 13.92 & 93.85 & 4.12 & 0.45 & 12.55 & 0.05 & 0.98 & 47.6 & 0.064 \\
\hline AVE. & 7.37 & 18.1 & 44.3 & 256.1 & 267 & 15.21 & 4.28 & 13.76 & 24.49 & 158 & 9.46 & 21.81 & 0.47 & 0.09 & 2.56 & 0.03 & 0.32 & 30.1 & 0.007 \\
\hline C.V. & 0.07 & 0.1 & 3.4 & 0.7 & 2.4 & 0.53 & 0.45 & 0.24 & 1.05 & 2.0 & 0.27 & 1.14 & 2.32 & 1.60 & 1.25 & 0.60 & 1.16 & 0.25 & 2.967 \\
\hline S.D. & 0.49 & 2.2 & 148.9 & 188.9 & 133 & 8.04 & 1.94 & 3.37 & 25.61 & 71.0 & 2.58 & 24.81 & 1.09 & 0.15 & 3.20 & 0.02 & 0.37 & 7.46 & 0.015 \\
\hline
\end{tabular}

be present (Appelo and Postma, 2005).

The silica content determined only during rainy season, and it presented high concentrations nearing $30 \mathrm{mg} \mathrm{L}^{-1}$, with a maximum value of $42 \mathrm{mg} \mathrm{L}^{-1}$ at well P2. In this case, weathering processes involving silicates would also contribute a portion of the cationic content in groundwater (Appelo and Postma, 2005; Halim et al., 2010; Sonkamble et al., 2012).

With respect to cations, the dominance of the sodium ion may be highlighted both in water from wells and natural springs, with an average value of $23 \mathrm{mg} \mathrm{L}^{-1}$. Calcium has an average content of $15 \mathrm{mg} \mathrm{L}^{-1}$, while magnesium has an average of $13 \mathrm{mg} \mathrm{L}^{-1}$ and potassium of $4 \mathrm{mg} \mathrm{L}^{-1}$. These proportions of cationic content could indicate water-rock interactions, whereby the weathering of minerals rich in silica and sodium (e.g. Na-feldspars) would be prevalent, the coprecipitation de $\mathrm{Ca}^{2+} \mathrm{y} \mathrm{Mg}^{2+}$ in minerals like clays (e.g. incongruent dissolution of plagioclase to montmorillonite and kaolinite) or ion exchange (Rahman et al., 2011; Sonkamble et al., 2012; MoralesArredondo et al., 2016).

Furthermore, for sample M7 a scenario of anthropogenic contamination may be suggested due to infiltration of urban wastewater and/or from agricultural activities (Appelo and Postma, 2005). The remaining samples present values that can be considered as a natural background concentration in volcanic aquifers $\left(<6 \mathrm{mg} \mathrm{L}^{-1}\right.$; Koh et al., 2009). In addition, the presence of $\mathrm{NH}_{4}^{+}\left(0.20-0.98 \mathrm{mg} \mathrm{L}^{-1}\right)$ was detected in some samples that presented negative Eh values (P2, P4. P5, P7 and P8).

It is also important to highlight the presence of $\mathrm{Fe}$ and $\mathrm{Mn}$ in both well and spring water. In wells P2, P7 and P8, concentrations ranging from 0.5 to $4.2 \mathrm{mg} \mathrm{L}^{-1}$ were found for Fe. At the same wells, high concentrations of Mn were observed $\left(0.20\right.$ to $\left.0.6 \mathrm{mg} \mathrm{L}^{-1}\right)$. In the case of springs, both ions are present at nearly all sampling sites, although in lesser concentrations, with values ranging from 0.01 to $0.09 \mathrm{mg} \mathrm{L}^{-1}$.

\subsection{Hydrogeochemical processes}

\subsubsection{Groundwater types}

A Piper diagram classified the water samples (Fig. 2), and the following four chemical families were differentiated: $\mathrm{Mg}-\mathrm{Na}-\mathrm{HCO}_{3}$ (majority of samples), $\mathrm{Na}-\mathrm{HCO}_{3}$ (wells P1 and P2), $\mathrm{Mg}-\mathrm{Ca}-\mathrm{HCO}_{3}$ (P8, P9

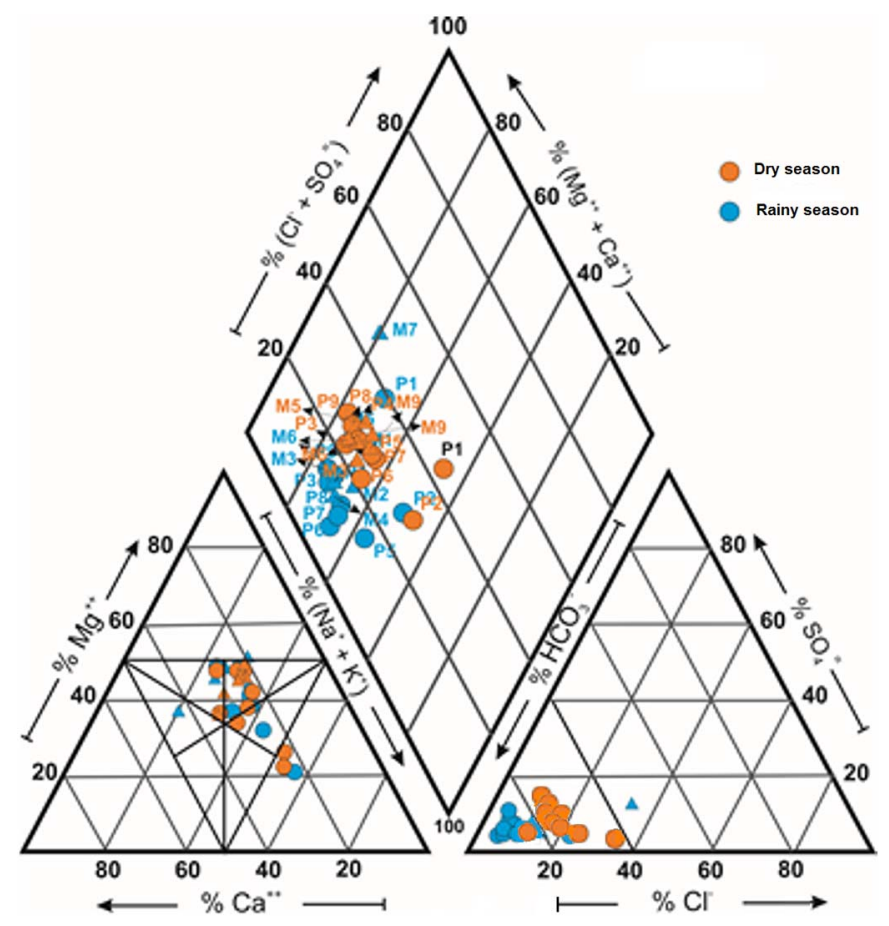

Fig. 2. Piper plot of groundwater samples of study area (P wells and M springs).

and M5) and Ca-Mg-HCO $(\mathrm{M} 7)$. Likewise, based on the Piper diagram, the chemistry of well water was found to be similar to spring water, except at P1, P2 and M7; little variation occurs between dry and rainy reasons. This overall homogeneity could indicate that the hydrogeochemical processes contributing to the mineral content of water have occurred under similar conditions remaining constant over time.

\subsubsection{Ion ratios in groundwater}

Relationships among physicochemical parameters were statistically 
Table 4

Spearman rho correlation coefficients among the physicochemical characteristics of groundwater samples $(\mathrm{n}=16, \mathrm{p}<0.05)$.

\begin{tabular}{|c|c|c|c|c|c|c|c|c|c|c|c|c|c|}
\hline \multicolumn{14}{|c|}{ Dry/rainy } \\
\hline & EC & TDS & Eh & $\mathrm{HCO}_{3}{ }^{-}$ & $\mathrm{SO}_{4}{ }^{2-}$ & $\mathrm{Cl}^{-}$ & $\mathrm{Mg}^{2+}$ & $\mathrm{Ca}^{2+}$ & $\mathrm{Na}^{+}$ & $\mathrm{K}^{+}$ & $\mathrm{Fe}$ & Mn & $\mathrm{Si}$ \\
\hline EC & 1 & & & & & & & & & & & & \\
\hline TDS & $0.79 / 0.71$ & 1 & & & & & & & & & & & \\
\hline Eh & $-1-$ & $-1-$ & 1 & & & & & & & & & & \\
\hline $\mathrm{HCO}_{3}{ }^{-}$ & $0.65 / 0.69$ & $0.95 / 0.96$ & & 1 & & & & & & & & & \\
\hline $\mathrm{SO}_{4}^{2-}$ & & & & & 1 & & & & & & & & \\
\hline $\mathrm{Cl}^{-}$ & $0.64 / 0.55$ & $0.58 /-$ & & & & 1 & & & & & & & \\
\hline $\mathrm{Mg}^{2+}$ & $0.68 / 0.50$ & $0.58 / 0.55$ & & $0.58 / 0.55$ & & & 1 & & & & & & \\
\hline $\mathrm{Ca}^{2+}$ & $0.66 / 0.69$ & $0.57 /-$ & & & & & & 1 & & & & & \\
\hline $\mathrm{Na}^{+}$ & $0.62 / 0.64$ & $0.83 / 0.89$ & & $0.86 / 0.93$ & & $0.60 /-$ & & & 1 & & & & \\
\hline $\mathrm{K}^{+}$ & $-/ 0.75$ & $0.53 / 0.71$ & & $0.51 / 0.66$ & & & & $0.59 / 0.60$ & $-/ 0.56$ & 1 & & & \\
\hline $\mathrm{Fe}$ & $-/ 0.68$ & $0.68 / 0.65$ & $-0.66 /-0.48$ & $0.58 / 0.64$ & & $0.67 /-$ & & $0.50 / 0.52$ & $0.63 / 0.57$ & $/ 0.58$ & 1 & & \\
\hline Mn & $-/ 0.64$ & $-/ 0.55$ & $-0.56 /-0.51$ & & $0.73 / 0.61$ & & & $0.52 / 0.23$ & & $/ 0.59$ & $0.72 / 0.92$ & 1 & \\
\hline $\mathrm{Si}$ & & & & $-/ 0.63$ & & & & & $-/ 0.59$ & & $-/ 0.50$ & & 1 \\
\hline
\end{tabular}

Coefficients are significant at the 0.05 level and those higher than 0.7 shown as bold font.

explored by generating a Spearman rho correlation coefficient matrix for each sampling period (Table 4). If the coefficient ( $\mathrm{r}$ ) is $>0.7$, two parameters are considered to be strong correlated, whereas if the value $\mathrm{r}$ is between 0.5 and 0.7 , it indicates a moderate correlation at a significance level $\mathrm{p}=0.05$ (Koh et al., 2009). Correlation analysis of the parameters showed:

- EC and TDS increases as $\mathrm{HCO}_{3}{ }^{-}, \mathrm{Cl}^{-}, \mathrm{Mg}^{2+}, \mathrm{Ca}^{2+}$ and $\mathrm{Na}^{+}$content increases $(r>0.6)$, whereby this chemical property is determined by the most abundant ions, which confer the characteristics of water identified in the Piper diagram.

- $\mathrm{HCO}_{3}{ }^{-}$content increases as $\mathrm{Na}^{+}$content increases $(\mathrm{r}>0.8)$. The correlation of $\mathrm{HCO}_{3}{ }^{-}$with $\mathrm{K}^{+}, \mathrm{Mg}^{2+}$ and $\mathrm{Fe}$ is also observed, although to a lesser extent ( $\mathrm{r}>0.5$ ).

- In rainy season, silica content is correlated with $\mathrm{HCO}_{3}{ }^{-}(\mathrm{r}=0.63)$ and also $\mathrm{Na}^{+}(\mathrm{r}=0.59)$ and $\mathrm{Fe}(\mathrm{r}=0.50)$. This correlation can be explained by acidic hydrolysis of silicate minerals in volcanic rocks (Koh et al., 2009; Halim et al., 2010; Rahman et al., 2011; Sonkamble et al., 2012).

- Specifically, in the case of $\mathrm{Fe}$, it is possible to observe a positive correlation with $\mathrm{Mn}$ in dry season $(\mathrm{r}=0.72)$, also the strength of this correlation increases in rainy season $(r=0.92)$. This correlation confirms the common chemical behavior of both of these metals (Stumm and Morgan, 1996).

- In dry season, redox potential of water decreases as Fe content increases $(r=-0.66)$; and $M n$ behavior is similar in dry $(r=-0.56)$ and rainy $(r=-0.51)$ seasons. This negative correlation could be an initial indication that dissolved Fe and Mn are under reduction conditions (Kazak and Pozdniakov, 2010; Appelo and Postma, 2005).

- Correlation was not found between $\mathrm{NO}_{3}{ }^{-}$and the rest of the evaluated variables, which is consistent with its assumed anthropogenic origin; although this assumption may not be correct since it must be noted that nitrate is present in low concentrations.

As evidenced by these correlations, several hydrochemical processes may be identified as part of an initial approximation and should be studied in detail.

\subsubsection{Processes controlling groundwater chemistry}

To assess the role of the dissolution mechanisms of carbonate compounds (including the effect of $\mathrm{CO}_{2}$ ) and the role of alteration of silicates, the relationship of $\mathrm{HCO}_{3}{ }^{-}$to $\mathrm{Ca}^{2+}+\mathrm{Mg}^{2+}$ was studied (Fig. 3a) to identify the prevailing processes (Rahman et al., 2011; Biswas et al., 2012). In Fig. 3a data are grouped above $\mathrm{y}=2 \mathrm{x}$ (dissolution of carbonates), indicating an additional contribution of $\mathrm{HCO}_{3}{ }^{-}$ (and a reduction in cations due to ionic exchange). This could be related to the alteration of silicates, oxidation of organic matter or respiration of plant roots (Mukherjee and Fryar, 2008). However, considering the characteristics of the study area (volcanic material), the most appropriate answer may involve the alteration of silicates, above all in samples from wells P1 and P2. These are separated from the other sampling points, indicating a distinct composition (and greater enrichment of $\mathrm{HCO}_{3}{ }^{-}$). In the case of natural springs, contribution of $\mathrm{CO}_{2}$ to water may be explained by mechanisms occurring in the soil, due to oxidation of organic matter and/or respiration of plant roots.

In the Fig. 3b, the relationship of $\mathrm{HCO}_{3}{ }^{-}$to $\mathrm{Na}^{+}+\mathrm{K}^{+}$is shown, and this may also be used to verify alteration of silicates and carbonates (Biswas et al., 2012). In this figure, the observation points tend to fall above $y=2 x$. Meanwhile, sampling points $\mathrm{P} 1$ and $\mathrm{P} 2$ are located below $\mathrm{y}=2 \mathrm{x}$ and near $\mathrm{y}=\mathrm{x}$ due to higher levels of sodium and potassium (Fig. 2), and possibly indicating an intense process of silicate alteration that could cause an enrichment of $\mathrm{Na}^{+}$and $\mathrm{K}^{+}$, as well as $\mathrm{HCO}_{3}{ }^{-}$, due to the effect of dissolution of feldspars with $\mathrm{Na}^{+}$and $\mathrm{K}^{+}$.

In Fig. 3c, the relationship between $\mathrm{Ca}^{2+}+\mathrm{Mg}^{2+}$ and total cations is presented (Sonkamble et al., 2012). It may be observed that points are located between $\mathrm{y}=\mathrm{x}$ (total cations $=\mathrm{Ca}^{2+}+\mathrm{Mg}^{2+}$ ) and $\mathrm{y}=2 \mathrm{x}$ (total cations $=2\left[\mathrm{Ca}^{2+}+\mathrm{Mg}^{2+}\right]$ ), with the exception of P1 and P2 above $y=2 x$. This distribution of points indicates that $\mathrm{Ca}^{2+}+\mathrm{Mg}^{2+}$ ions would originate from the attack of minerals rich in these cations, such as alkaline earth silicate, and in the case of P1 and P2, from the attack of alkaline feldspars, which would contribute $\mathrm{Na}^{+}$and $\mathrm{K}^{+}$. In Fig. $3 \mathrm{~d}\left(\mathrm{Na}^{+}+\mathrm{K}^{+}\right.$vs total cations), it is observed that nearly all of the samples are located above $\mathrm{y}=2 \mathrm{x}$ (total cations $=2\left[\mathrm{Na}^{+}+\mathrm{K}^{+}\right]$), indicating a lesser contribution of $\mathrm{Na}^{+}+\mathrm{K}^{+}$. Meanwhile, P1 and P2 are located below the straight line, due to the contribution of $\mathrm{Na}^{+}$and $\mathrm{K}^{+}$ by alteration of silicates.

Wells P1 and P2 are distinctive due to their operation $24 \mathrm{~h}$ a day, which may imply that groundwater is pumped from a greater depth and distance. This is characteristic of an intermediate flow regime (OrtegaGuerrero, 2009; González-Abraham et al., 2012), which indicates a prolonged residence time of water, enabling it to circulate through the base of the aquifer largely consisting of andesites and leading to a higher mineral content.

The presence of silica, bicarbonate ions (considering the correlation of $\mathrm{Si}$ and $\mathrm{HCO}_{3}{ }^{-}$is $\mathrm{r}=0.78$, Table 4) and $\mathrm{Na}^{+}, \mathrm{K}^{+}$and $\mathrm{Ca}^{2+}$ in groundwater may be linked with the incongruent dissolution of plagioclases. For example, the dissolution of albite (which contributes $\mathrm{Na}^{+}$) leads to presence of kaolinite (Eq. (1)), Na-montmorillonite (Eq. (2)) and/or gibbsite (Eq. (3)). These all have Al, which is highly insoluble and tends to precipitate (Appelo and Postma, 2005). In addition, incongruent dissolution could occur with orthoclase (contributes $\mathrm{K}^{+}$) and 

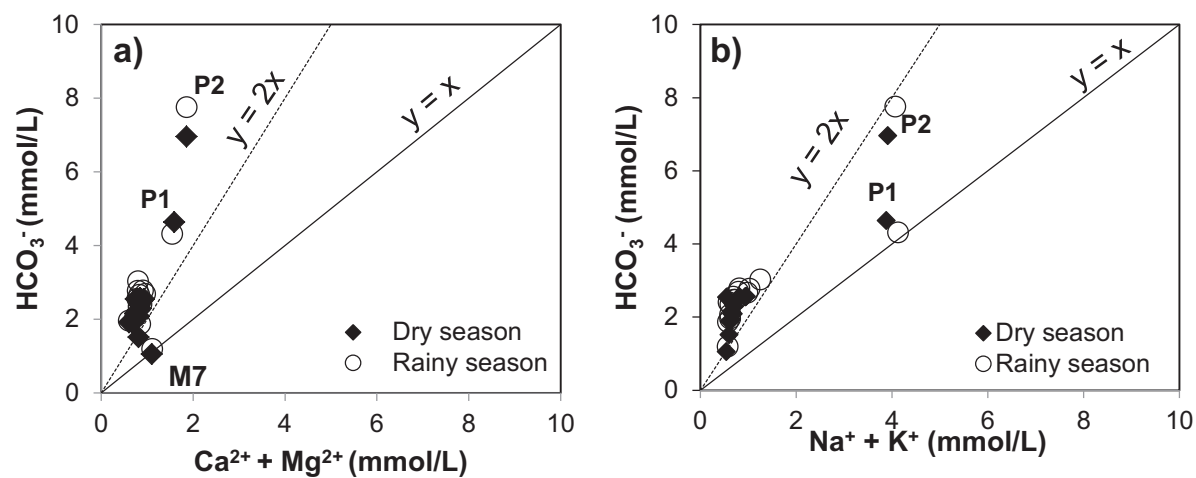

Fig. 3. Bivariate plots of a) $\mathrm{HCO}_{3}{ }^{-}$versus $\mathrm{Ca}^{2+}+\mathrm{Mg}^{2+}$, b) $\mathrm{HCO}_{3}{ }^{-}$versus $\mathrm{Na}^{+}+\mathrm{K}^{+}$, c) $\mathrm{Ca}^{2+}+\mathrm{Mg}^{2+}$ versus total cations, and d) $\mathrm{Na}^{+}+\mathrm{K}^{+}$versus total cations, to illustrate carbonate and silicate weathering in groundwater.
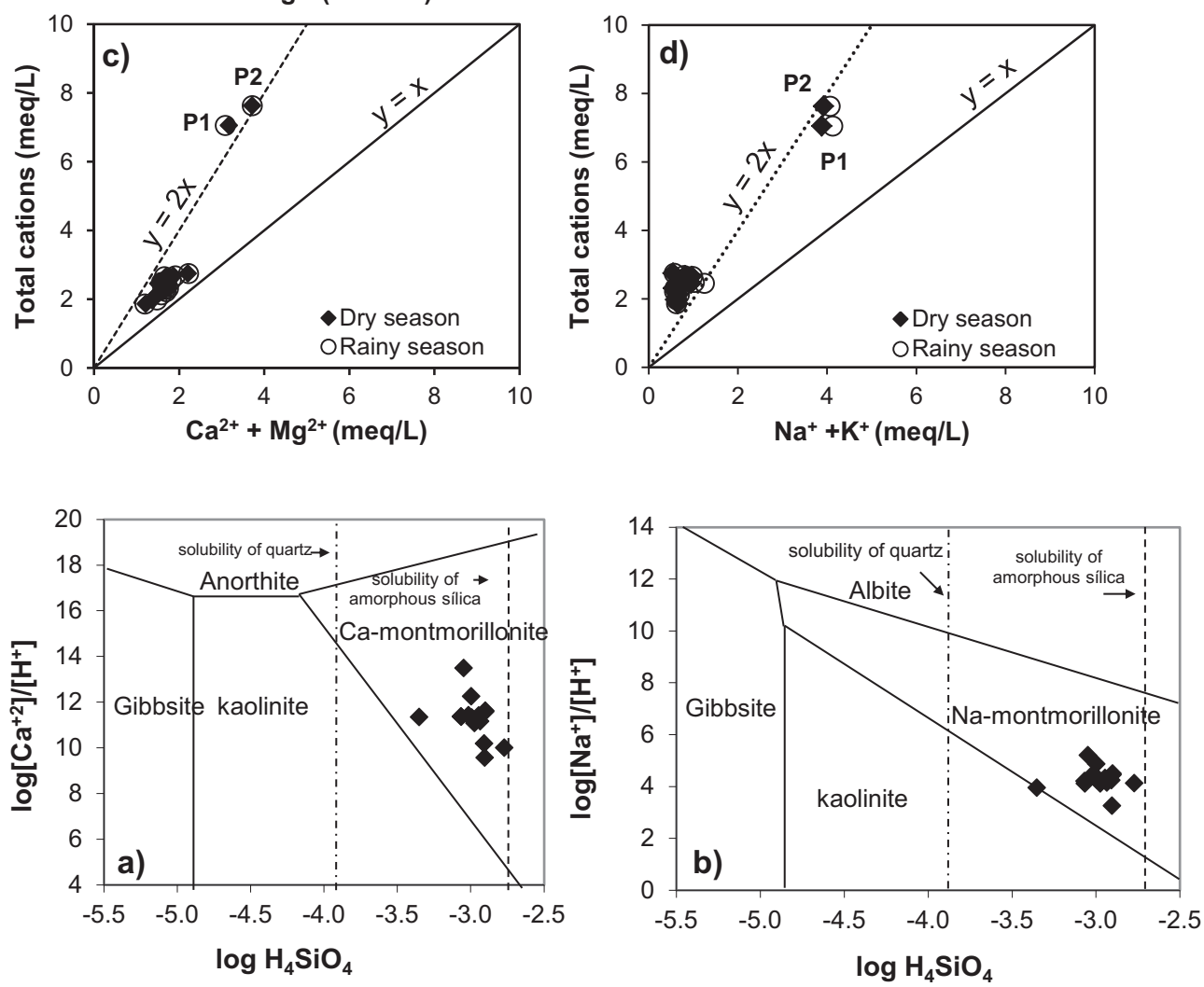

Fig. 4. Stability of a) Ca-Al silicate phases, b) Na$\mathrm{Al}$ silicate phases, and c) $\mathrm{K}-\mathrm{Al}$ silicate phases in aqueous solution at $25^{\circ} \mathrm{C}$ and $1 \mathrm{~atm}$ pressure with groundwater data of study area.

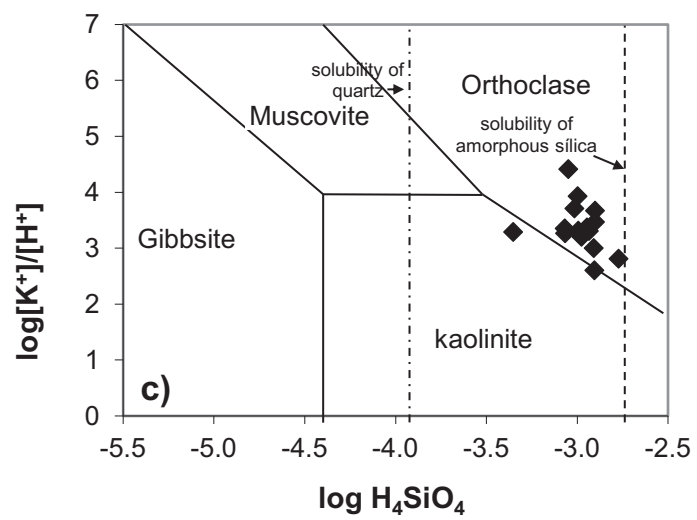

anorthite (contributes $\mathrm{Ca}^{2+}$ ), as is shown in Eqs. (4), (5) and (6). Other reactions with mafic minerals (Eqs. (7), (8) and (9)) give place to the presence of $\mathrm{Mg}^{2}{ }^{+}, \mathrm{HCO}_{3}{ }^{-}$and $\mathrm{Si}$ in groundwater.

To study the occurrence of incongruent dissolution, in Fig. 4 stability diagrams of $\mathrm{Ca}-\mathrm{Al}, \mathrm{Na}-\mathrm{Al}$ and $\mathrm{K}-\mathrm{Al}$ silicate phases are presented (Mukherjee and Fryar, 2008; Halim et al., 2010; Jalali, 2010; Jalali and Jalali, 2016). Water samples are found in the stability field of Namontmorillonite and Ca-montmorillonite (Eqs. (2) and (6)). Thus, albite and anorthite would be unstable, favoring their dissolution and contribution to the presence of both $\mathrm{Ca}^{2+}$ and $\mathrm{Na}^{+}$in groundwater. Accordingly, correlation of $\mathrm{Si}$ and $\mathrm{Na}^{+}$would be moderate $(\mathrm{r}=0.61$, Table 4), although correlation of $\mathrm{Si}$ with $\mathrm{Ca}^{2+}$ is lower $(\mathrm{r}=0.30$, Table 4). Meanwhile, orthoclase (microcline) tends to be stable, therefore its dissolution would not be the main source of $\mathrm{K}^{+}$(supported by low correlation between $\mathrm{Si}$ and $\mathrm{K}^{+} ; \mathrm{r}=0.43$, Table 4). Based on these data, the reactions involving the incongruent dissolution of albite 


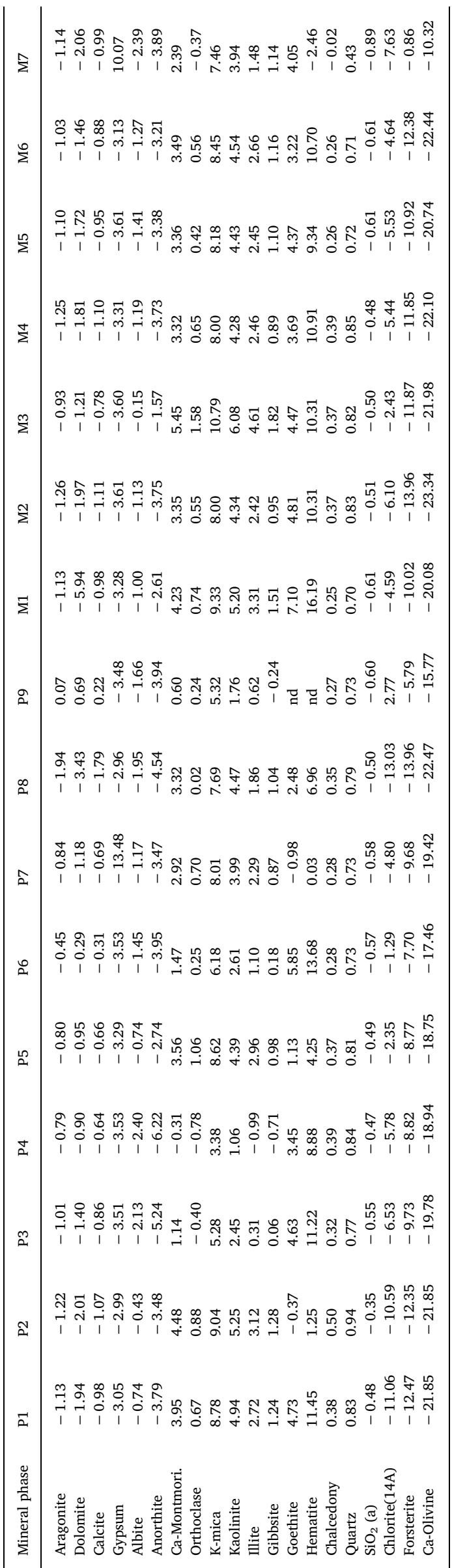

to Na-montmorillonite (Eq. (2)) and anorthite to Ca-montmorillonite (Eq. (6)) would be mostly favored in this aquifer.

The results shown in Fig. 4 can also be checked by calculating the saturation indices. Table 5 shows the SI values of groundwater. Water samples were undersatured (dissolution) with respect to albite and anorthite and oversatured (precipitation) with respect to Ca-montmorillonite, kaolinite and gibbsite. P3 and P4 samples were undersatured with respect to orthoclase but other samples tend to precipitate orthoclase. Water samples were undersatured with respect to $\mathrm{SiO}_{2}$ (amorphous) and oversatured with respect to quartz and chalcedony. Therefore, possible sources of silica in groundwater include weathering of feldspars and silica amorphous.

These results may be compared to those presented by several authors. Halim et al. (2010) propose this process of silicate weathering to explain the hydrochemistry of a detritic aquifer dominated by quartz with some plagioclase and potassium feldspars and volcanic, metamorphic and sedimentary fragments. Parisi et al. (2011) studied a volcanic aquifer using the stability diagrams and the saturation indexes, and verified that the most waters fall in the kaolinite stability field, proposing that the short interaction of groundwater with the silicates minerals would produce kaolinite only. Morales-Arredondo et al. (2016) studied a volcanic-sedimentary aquifer composed of basalts, rhyolite tuffs, ignimbrite and alluvial deposits, and report the hydrolysis of anorthite, albite and orthoclase, and observe that the water samples fall within the kaolinite and Ca-montmorillonite stability fields. Morán-Ramírez et al. (2016) investigated rock-water interactions in a volcanic system aquifer (a granular upper aquifer consists of pumicic and volcanic ash with interbedded basaltic lava, and a fractures lower aquifer consists of basaltic -andesitic rocks) by using a model equilibrium calculation. They found out that the samples are undersatured to albite and close to saturation with respect to silica amorphous. Also, they found out that majority of the samples plot in the stability field of kaolinite and some samples plot in the K-feldspar field. For the Tenancingo Valley aquifer, all the waters fall in the Na-montmorillonite and orthoclase stability fields (Fig. 4b and c). A prolonged interaction (with a low flushing rate and long residence time) of groundwater with silicate minerals would allow equilibrium with $\mathrm{Na}$ montmorillonite (Parisi et al., 2011).

Upon characterizing processes involved in alteration of silicates, ionic exchange must be considered due to its effect on the enrichment or depletion of cation concentrations. In order to identify the possible process of ionic exchange, the relationship between $\mathrm{Cl}^{-}$and $\mathrm{Na}^{+}$was first considered (Fig. 5a), as water was lightly enriched with $\mathrm{Na}^{+}$. Thus, the $\mathrm{Na}^{+} / \mathrm{Cl}^{-}>1$ relationship may be interpreted as representative of the weathering of silicates (alkaline feldspar) or a process of ionic exchange (Jalali, 2010). In addition, the differences between wells P1 and P2 may be highlighted in this Fig. 5a. In spring M7, an anthropogenic contribution may exist in the form of irrigation run-off or leaching of wastewater, leading to the enrichment of chlorine in water.

Another means of verifying ionic exchange is by the graph of the relationship of $\left[\left(\mathrm{Ca}^{2+}+\mathrm{Mg}^{2+}\right)-\left(\mathrm{HCO}_{3}{ }^{-}+\mathrm{SO}_{4}{ }^{2-}\right)\right] \mathrm{vs}$. $\left(\mathrm{Na}^{+}-\mathrm{Cl}^{-}\right)$. In this graph (Fig. 5b), $\mathrm{Ca}^{2+}+\mathrm{Mg}^{2+}$ concentration is corrected by $\mathrm{HCO}_{3}{ }^{-}+\mathrm{SO}_{4}{ }^{2-}$, to exclude the contribution of ions from carbonates and silicates. $\mathrm{Na}^{+}$concentration is corrected by $\mathrm{Cl}^{-}$to exclude $\mathrm{Na}^{+}$ from atmospheric deposition (Jalali, 2006; Biswas et al., 2012). In aquifers affected by processes of ion exchange, data represented in this graph allows for the adjustment of the straight line with a negative slope, suggesting the existence of an exchange process. To the contrary, all data would group at the origin of the coordinate system. In this case, a straight line with a slope of -1.8 and a $\mathrm{r}^{2}=0.82$ is obtained, indicating that $\mathrm{Na}^{+}+\mathrm{K}^{+}$would be released and $\mathrm{Ca}^{2+}+\mathrm{Mg}^{2+}$ would be fixed.

\subsubsection{Processes controlling Fe and Mn solute distribution}

The spatial distribution of $\mathrm{Fe}$ and $\mathrm{Mn}$ values confirms that their greatest concentrations are found in the alluvial zone of the study area, 

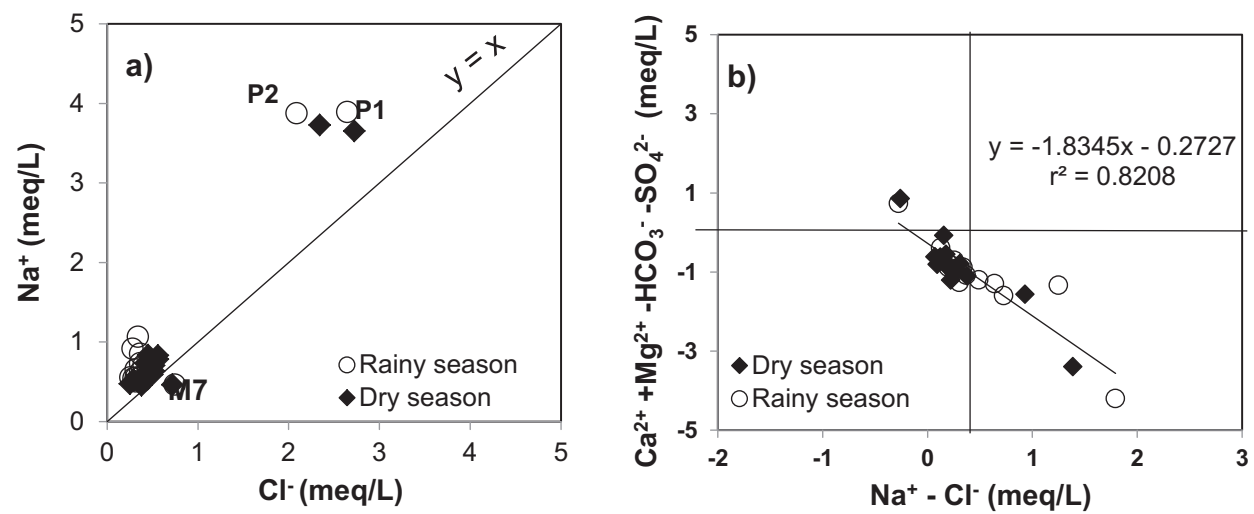

Fig. 5. Bivariate plots of a) $\mathrm{Cl}^{-}$versus $\mathrm{Na}^{+}$, and b) $\left[\left(\mathrm{Ca}^{2+}+\mathrm{Mg}^{2+}\right)-\left(\mathrm{HCO}_{3}^{-}+\mathrm{SO}_{4}{ }^{2-}\right)\right]$ versus $\left(\mathrm{Na}^{+}\right.$. $\mathrm{Cl}^{-}$). which is also undergoing the most intense water exploitation (Fig. 6). An intermediate flow occurs in this section of the aquifer, enabling the dissolution of a geological matrix that may contain mafic minerals (biotite, hypersthene, olivine Eqs. (10), (11) and (12)). Under these conditions, mafic minerals are then weathered due to the prolonged residence time of groundwater.

To study this process, the IS of forsterite and Ca-Olive were calculated (Table 5). In well samples, the IS respect to both minerals fluctuated between -5.8 and -12.47 to forsterite (undersaturated) and between -17.6 and -22.4 to Ca-olivine (undersaturated). In spring samples, the extreme values of the IS respect to forsterite were -10.1 and -13.6 , and respect to Ca-olivine were -20.1 and -23.3 . This data suggest the weathering of mafic minerals.

Once released $\mathrm{Fe}$ and $\mathrm{Mn}$ into groundwater from the geological matrix, the presence of $\mathrm{Fe}$ and $\mathrm{Mn}$ in soluble form is conditioned by the redox state, as shown in Fig. 7. A tendency for Eh to have positive values (oxidizing environment) when the concentration of these ions is lower may be observed, while negative Eh values (reducing environment) are associated with higher ion concentration. It may also be observed that a reducing environment is detected only in wells (Tables
2 and 3). To explain the importance of this factor, the conclusions of Smith and Roychoudhury (2013) may be highlighted; they found mineral dissolution in a reducing environment to be the most effective process to affect the release of $\mathrm{Fe}$, independent of $\mathrm{pH}$.

Other factors may be considered, such as $\mathrm{pH}$, presence of organic acids (organic matter) or levels of salinity (ionic strength or TDS) (Weng et al., 2007; Smith and Roychoudhury, 2013; Carretero and Kruse, 2014). In the case of $\mathrm{pH}$, several authors have shown that in oxidizing conditions, the concentration of Fe increased with a decrease in pH (Smith and Roychoudhury, 2013; Carretero and Kruse, 2014).

In addition, salt content of water has been identified as another controlling factor (Weng et al., 2007), since water with high ionic strength has greater concentrations of Fe and Mn. High ionic strength indicates existence of anionic complexes with which Fe and Mn could bond, resulting in a greater solubility of both elements. The relationship between saline content and high Fe and Mn concentrations in water is supported by the present case. In Table 4 a positive correlation of EC with both $\mathrm{Fe}(\mathrm{r}=0.68)$ and $\mathrm{Mn}(\mathrm{r}=0.64)$ is observed.

In the speciation diagrams, it may be confirmed that Fe and Mn exist in soluble form in water. In Fig. 8, it is shown that Fe and Mn may be
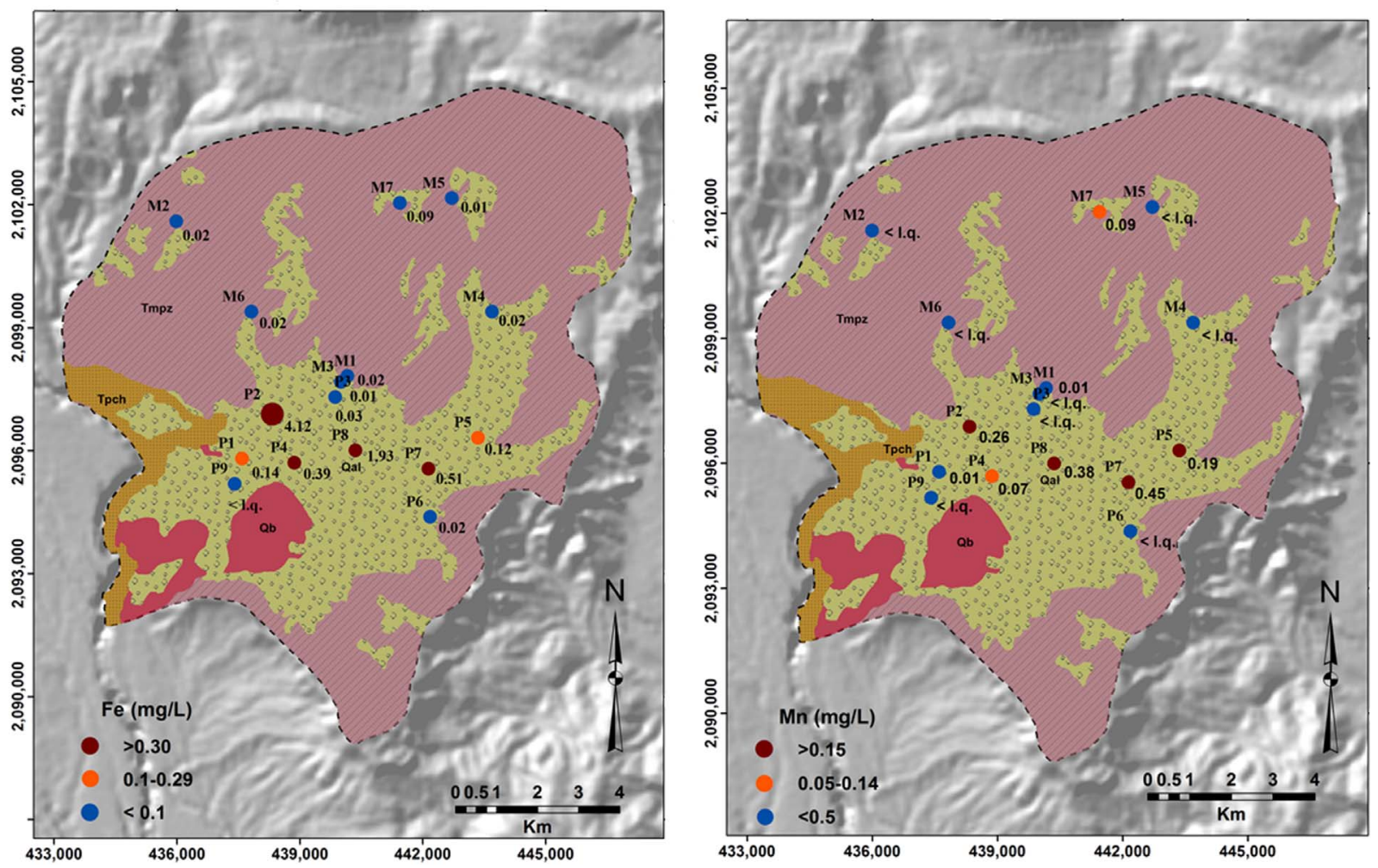

Fig. 6. Spatial distribution of a) Fe, and b) Mn in groundwater of study area. 

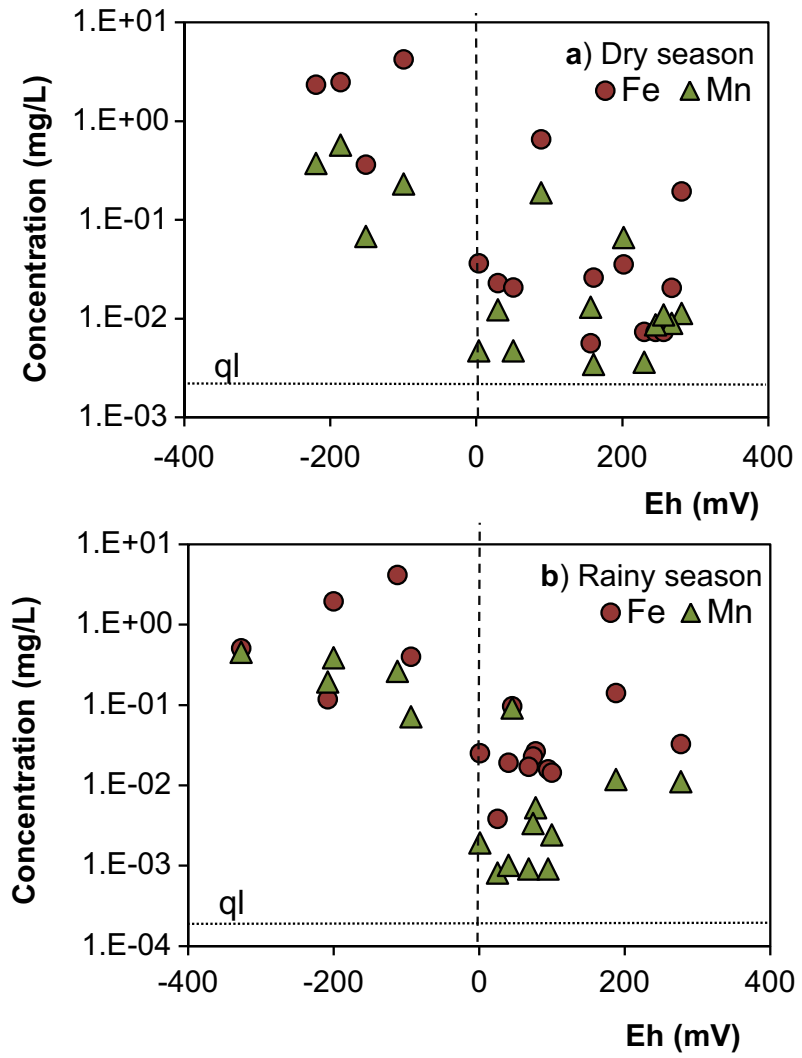

Fig. 7. Diagram of Eh (mV) and concentrations of Fe y Mn $\left(\mathrm{mg} \mathrm{L}^{-1}\right)$ for the groundwater samples from a) dry season, and b) rainy season (P: wells; M: sprigs).

dissolved in groundwater at $\mathrm{pH}$ values of 6.6-8.5 and at redox potentials of -0.2 to $+0.3 \mathrm{~V}$. At neutral $\mathrm{pH}$, concentration of $\mathrm{Mn}^{2+}$ and possibly $\mathrm{Fe}^{2+}$ may be influenced by other factors, including their formation of complexes with bicarbonates and sulfates (if these have high concentrations) (Homoncik et al., 2010).

In order to achieve information on the presence of Fe and Mn forms, the ion speciation of these elements were calculated by PHREEQC. The results show that $\mathrm{Fe}$ and $\mathrm{Mn}$ were dominated by free ions. Samples with negative Eh have values close to $100 \%$ of the $\mathrm{Fe}^{2+}$ free. In some of these samples the presence of and $\mathrm{Fe}(\mathrm{HS})_{2}$ with values around $2 \%$ was identified also. In samples with Eh positive, Fe was also identified as $\mathrm{Fe}^{3+}$ free, and $\mathrm{Fe}(\mathrm{OH})^{+}$and $\mathrm{FeSO}_{4}$ with values between 0.2 and $3 \%$. The $\mathrm{Mn}^{2+}$ free was calculated to $100 \%$ of total $\mathrm{Mn}$ in groundwater. These data match well with what has been suggested by the speciation diagrams (Fig. 8).

\subsubsection{Anthropogenic processes}

Content of $\mathrm{NO}_{3}{ }^{-}$in water at springs M5 and M7 (8.8 and $46.3 \mathrm{mg} \mathrm{L}^{-1}$, respectively) for dry season is greater than that of wells (average concentration of $2.5 \mathrm{mg} \mathrm{L}^{-1}$ ) (Tables 2 and 3). This may indicate that the groundwater receives a contribution of $\mathrm{NO}_{3}{ }^{-}$as a consequence of the poor natural protection of springs from potential sources of contamination stemming from agricultural activities and domestic wastewater run-off.

\subsection{Conceptual model}

As a final result, a conceptual model was created and is presented in Fig. 9 as a diagram of a hydrological section including two aquifer units (detritic upper aquifer and volcanic lower aquifer), in addition to a hypothetical framework for groundwater flow. The position of several wells and their physicochemical characteristics are also detailed. Under conditions of exploitation, the wells with intense extraction regimes have a withdrawal of groundwater table level. At the location of wells P1 and P2, there is a cone of depression.

This Fig. 9 may serve as a basis for highlighting the origin of dissolved ions and explaining some of the processes that determine the physicochemical evolution of water in the aquifer, including the following:

- Anionic content of water in wells and springs is dominated by $\mathrm{HCO}_{3}{ }^{-}$, proceeding from chemical reactions produced by interaction of water and gas (atmospheric $\mathrm{CO}_{2}$-soil-vadose zone), as well as alteration of silicates (plagioclases and mafic minerals).

- Lower concentrations of $\mathrm{Cl}^{-}$correspond to the mountain-valley boundary (young waters), increasing with time of transit through the aquifer (increasing residence time) and reaching their maximum at the discharge zone (central portion of the aquifer).

- During water transit through the aquifer, enrichment of $\mathrm{Na}^{+}$is observed, reaching a maximum concentration at the discharge area. Considering the dominance of alkaline rocks in this study area, this ion may result from incongruent dissolution of sodium plagioclases, as well as processes of ionic exchange.

- Water extracted from wells P1 and P2 represents a mixture with water of a higher mineral content, which is linked to an intermediate groundwater flow. Dissolution of mafic minerals enriches the groundwater with $\mathrm{Fe}$ and $\mathrm{Mn}$. The reduction processes conditioned the presence of $\mathrm{Fe}$ and $\mathrm{Mn}$ in soluble forms.

- Although groundwater flows quickly through the fractured unit of the aquifer, spring water also contains $\mathrm{Fe}$ and $\mathrm{Mn}$.

- Presence of nitrates was detected in both well and spring water with a maximum of $5 \mathrm{mg} \mathrm{NO}_{3}{ }^{-} \mathrm{L}^{-1}$ at $\mathrm{P} 1$ and $46 \mathrm{mg} \mathrm{NO}_{3}{ }^{-} \mathrm{L}^{-1}$ at M7. The nitrate content of spring water may be attributed to anthropogenic contamination (irrigation return flow, use of fertilizers, leaching of organic residues, wastewater).
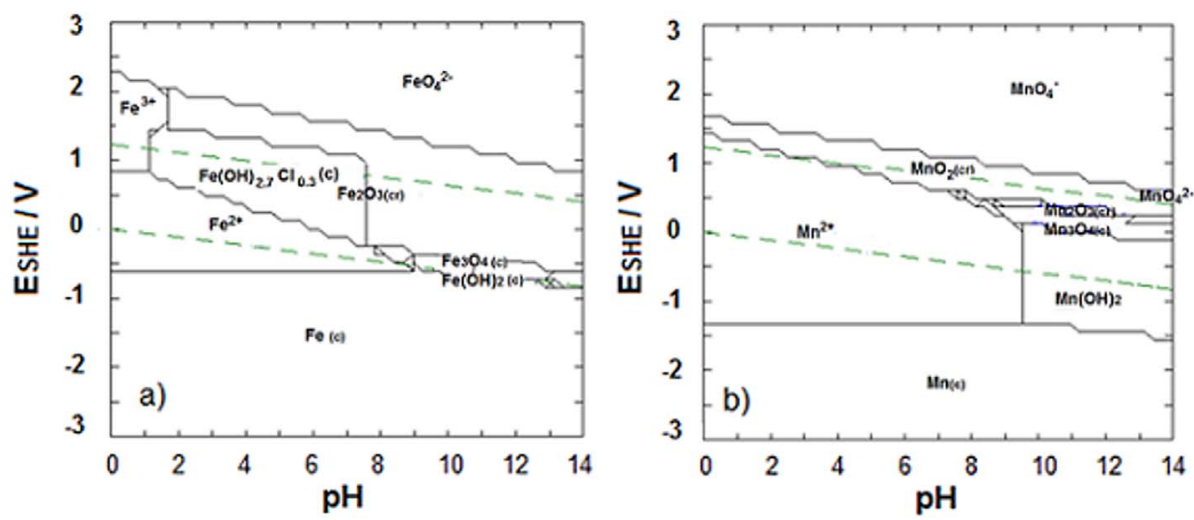

Fig. 8. Fields of stability for solid and dissolved forms of Fe and $\mathrm{Mn}$ as a function of $\mathrm{Eh}$ and $\mathrm{pH}$, for sample $\mathrm{P7}$ of dry season. System a) Fe-Cl-H, and b) Fe-Mn-Cl-H at $25{ }^{\circ} \mathrm{C}$, with I (ionic strength) of $0.000165 \mathrm{M}$ 

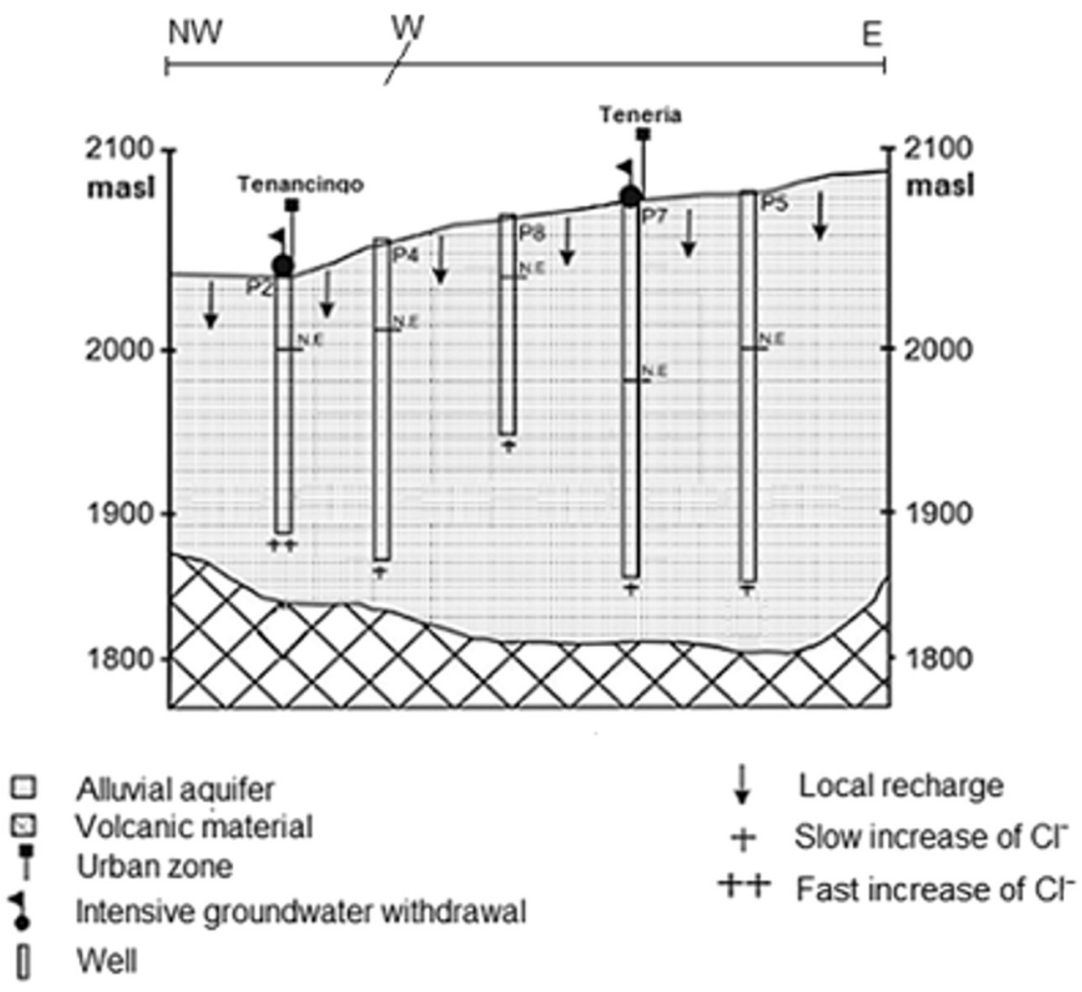

\begin{tabular}{lccccc}
\hline \multicolumn{1}{c}{ ID WELL } & P2 & P4 & P8 & P7 & P5 \\
\hline Elevation $(\mathrm{m}$ asl) & 2028 & 2043 & 2049 & 2054 & 2068 \\
Well depth $(\mathrm{m})$ & 150 & 200 & 100 & 200 & 200 \\
Depth to GW $(\mathrm{m})$ & 38 & 47 & 15 & 60 & 43 \\
Q $\left(\mathrm{Ls}^{-2}\right) /$ pumping time & $52 / 24 \mathrm{~h}$ & $36 / 24 \mathrm{~h}$ & $60 / 1 \mathrm{~h}$ & $16 / 6 \mathrm{~h}$ & $4 / 4 \mathrm{~h}$ \\
Type & $\mathrm{Na}-\mathrm{HCO}$, & $\mathrm{Na}-\mathrm{Mg}-\mathrm{HCO}$, & $\mathrm{Ca}-\mathrm{Mg}-\mathrm{HCO}$, & $\mathrm{Na}-\mathrm{Mg}-\mathrm{HCO}$, & $\mathrm{Na}-\mathrm{Mg}-\mathrm{HCO}$, \\
$\mathrm{Fe}\left(\mathrm{mgL}^{-1}\right)$ & $4.18-4.12$ & $0.06-0.07$ & $0.36-0.38$ & $0.56-0.45$ & $0.18-0.19$ \\
$\mathrm{Mn}\left(\mathrm{mgL}^{-1}\right)$ & $0.22-0.26$ & $0.36-0.39$ & $2.32-1.92$ & $2.46-0.51$ & $0.64-0.12$ \\
\hline
\end{tabular}

Fig. 9. Hydrogeochemistry framework along a transect of the aquifer. See Fig. 1 for cross section line location. See Table 1 for well data.

\subsection{Human consumption and irrigation use}

In this study, the complete set of physicochemical characteristics of water, as outlined in Mexican drinking water regulations (NOM-127SSA1-1994, 2000), has not been evaluated. In considering this limitation, water is apt for human use and consumption at wells P1 and P3 and at springs M1 and M6 (Tables 1 and 2). At the rest of the sampling points, water should receive a treatment to adjust $\mathrm{pH}$ and reduce concentrations of $\mathrm{Fe}, \mathrm{Mn}$ and $\mathrm{NO}_{3}{ }^{-}$, as necessary.

With respect to water use for irrigation, according to the Wilcox diagram (Fig. 10a), the relationship between the percentage of sodium and EC slightly varies between dry and rainy seasons, from "good to admissible" in well P2 and from "excellent to good" in the rest of the evaluated wells and springs. Water of well P1, in addition to having a greater percentage of sodium than P2, is also at the limit of the "excellent to good" classification, and a slight increase in electric conductivity may lower its quality to "good to admissible." Based on this classification, water may be used for agricultural irrigation throughout the course of the year.

In the diagram from the US Salinity Laboratory (Fig. 10b), water classifications vary slightly between dry and rainy seasons. In dry season, $87.5 \%$ of the sampled points correspond with C1S1, $6.25 \%$ with class C2S1 and the rest with class C3S1. This signifies that during dry season, $87.5 \%$ of water has low sodium content and may be used to irrigate any type of soil with low or null probability of creating saline conditions. Of the samples, $6.25 \%$ with "average salinity" may be used for irrigating crops with moderate or low levels of erosion, yet the majority of crops are nonresistant to these conditions without specialized control practices. The remaining $6.25 \%$ may be used in soil with good drainage and in salt-resistant crops.

\section{Conclusions}

The physicochemical characteristics of groundwater were evaluated during the present hydrogeochemical study of the Tenancingo Valley aquifer. The principal natural and anthropogenic processes that control these characteristics were also identified. The conclusions of this study may be highlighted, at following:

- In this unconfined volcanic-sedimentary aquifer, groundwater flow circulates from the northern, eastern and southern boundaries of the aquifer towards the central portion, which represents the zone of greatest discharge (highest intensity of groundwater pumping). After passing through the central zone, groundwater flows towards the west.

- Four chemical families were differentiated: $\mathrm{Mg}-\mathrm{Na}-\mathrm{HCO}_{3}$ (majority of samples), $\mathrm{Na}-\mathrm{HCO}_{3}$ (wells $\mathrm{P} 1$ and P2), $\mathrm{Mg}-\mathrm{Ca}-\mathrm{HCO}_{3}$ (P8, P9 and M5) and Ca-Mg- $\mathrm{HCO}_{3}$ (M7).

- The $\mathrm{HCO}_{3}{ }^{-}$parameter may be highlighted for its importance in the processes that control the chemical composition of water, as anions are dominant. The content of $\mathrm{HCO}_{3}{ }^{-}$results due to the interaction of water and $\mathrm{CO}_{2}$ from the atmosphere and soil-vadose zone. In this 

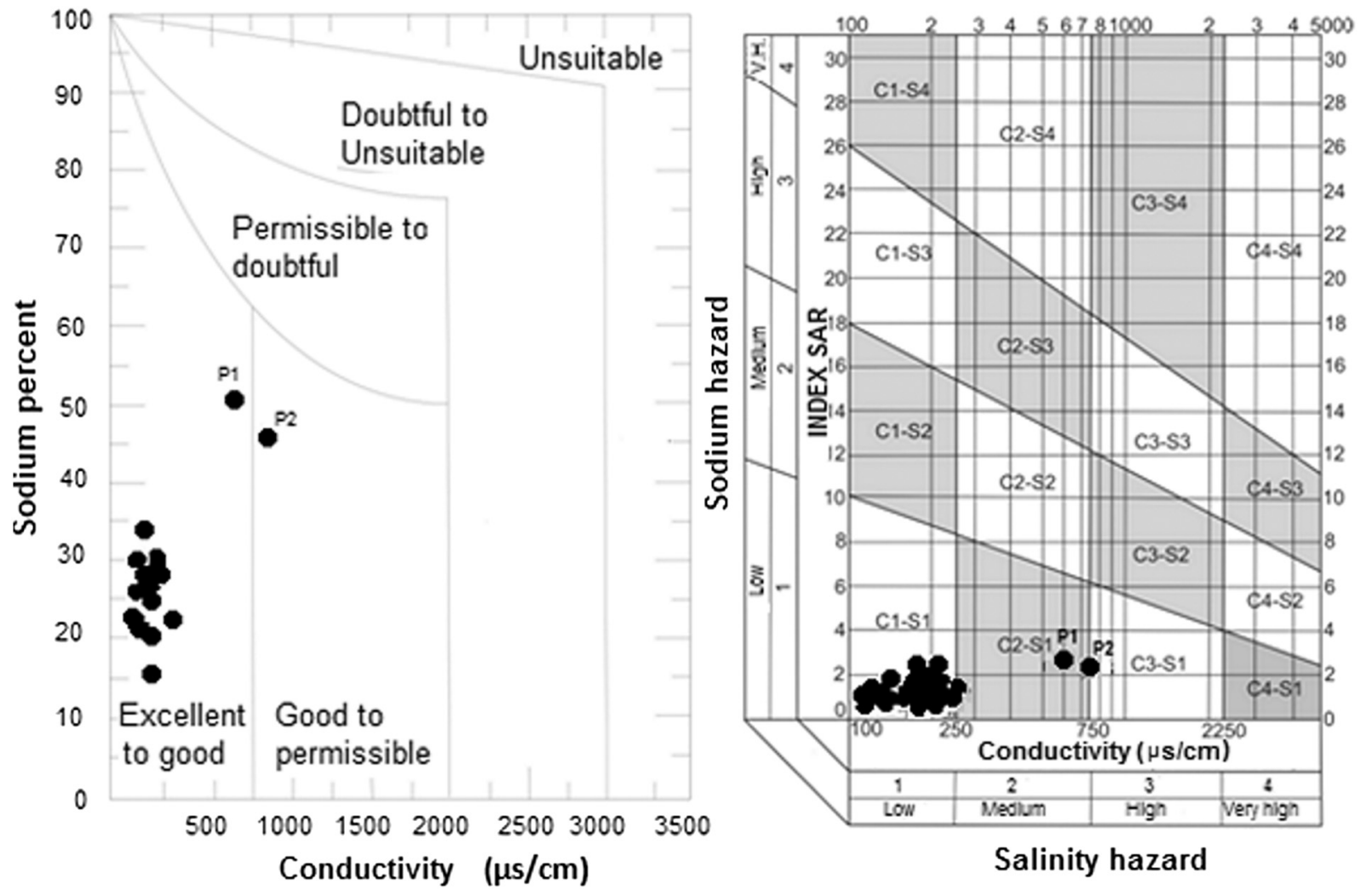

Fig. 10. Classification of irrigation water based on a) Wilcox diagram and b) US salinity diagram.

case, $\mathrm{CO}_{2}$ modifies the corrosive power of water and thus, its mineral content.

- The weathering of silicates is an additional process that leads to the enrichment of the ions in groundwater. The reactions involving the incongruent dissolution of albite to Na-montmorillonite and anorthite to Ca-montmorillonite would be mostly favored in this aquifer and contribute in the presence of $\mathrm{HCO}_{3}{ }^{-}, \mathrm{Ca}^{2+}, \mathrm{Na}^{+}$and $\mathrm{Si}$ in groundwater. Biotite, augite, olivine and hypersthene were present in the geological matrix and could have served as a source of $\mathrm{Fe}$ and $\mathrm{Mg}$. The ionic exchange must be considered indicating that $\mathrm{Na}^{+}+\mathrm{K}^{+}$would be released and $\mathrm{Ca}^{2+}+\mathrm{Mg}^{2+}$ would be fixed.

- Data from this study suggests that processes of water-rock interaction lead to the incorporation of Fe and Mn from the geological matrix to groundwater; elevated concentrations of $\mathrm{Fe}$ and $\mathrm{Mn}$ ions are detected in samples with negative Eh.

- The redox potential values ranged from - 219 to $327 \mathrm{mV}$, indicating the existence of reducing zones. Presence of Fe and Mn was detected in both springs and wells; concentrations were higher in wells, exceeding $4 \mathrm{mg} \mathrm{Fe} \mathrm{L}^{-1}$ and $0.5 \mathrm{mg} \mathrm{Mn} \mathrm{L}^{-1}$.

- The presence of $\mathrm{NO}_{3}{ }^{-}$of spring water could be an indicator of anthropogenic contamination.

- Factors that influence the hydrogeochemistry of groundwater include the characteristics of water exploitation, residence time of water, geological environment, redox conditions and the vulnerability of the aquifer to contamination.

- Water in wells P1 and P3 and in springs M1 through M6 is apt for human consumption and use, considering the evaluated parameters. At the other sampling points, water requires purification to adjust $\mathrm{pH}$ and decrease concentrations of $\mathrm{Fe}$ and $\mathrm{Mn}$, as necessary. For agricultural irrigation purposes, water at $86 \%$ of the sampling points may be used without restrictions.

Based on this, if adequate criteria and parameters for managing the Tenancingo Valley aquifer are not established, over time areas impacted by presence of $\mathrm{Fe}, \mathrm{Mn}$ and $\mathrm{NO}_{3}{ }^{-}$will increase and gradually generate a greater risk to public health and the environment.

Therefore, it is imperative to make a rational use of water in the area, search for new sources of water supply and consider that treatment of groundwater will become more expensive in the future due to increasing concentrations of $\mathrm{Fe}, \mathrm{Mn}$ and $\mathrm{NO}_{3}{ }^{-}$.

\section{Acknowledgments}

To the Water Commission of the State of Mexico for their assistance in the compilation of historical data, as well as for their logistical support during sampling. This research was financed by the Autonomous University of the State of Mexico (Grant number 2600/ 2008U). The authors are also pleased to thank Professor Simon Pirc (Associate Editor) and two reviewers for their thoughtful, constructive and useful comments, which improve the manuscript.

\section{References}

Álvarez-Bastida, C., Martínez-Miranda, V., Vázquez-Mejía, G., Solache-Ríos, M., FonsecaMontes de Oca, G., Trujillo-Flores, E., 2013. The corrosive nature of manganese in drinking water. Sci. Total Environ. 447, 10-16. http://http/dx.doi.org/10.1016/j. scitotenv.2013.01.005.

APHA (American Public Health Association), AWWA (American Water Works Association) y WFPC (Water Pollution Control Federation), 2005. Standard Methods for the Examination of Water and Wastewater, 21th edn. APHA, AWWA, WEF, Washington, D.C.

Appelo, C., Postma, D., 2005. Geochemistry, Groundwater and Pollution, 2nd Ed. A.A. Balkema Publishers, Rotterdam.

BGS (British Geological Survey), 2003. Water Quality Fact Sheet: Manganese

Biswas, A., Nath, B., Bhattacharya, P., Halder, D., Kundu, A.K., Mandal, U., Mukherjee, A., Chatterjee, D., Mörth, C.M., Jacks, G., 2012. Hydrogeochemical contrast between brown and grey sand aquifers in shallow depth of Bengal Basin: consequences for sustainable drinking water supply. Sci. Total Environ. 431, 402-412. http://http/dx. doi.org/10.1016/j.scitotenv.2012.05.031.

CAEM (Comisión del Agua del Estado de México), 2012. Informe de análisis de agua para consumo humano. In: Dirección de Operación y Mantenimiento. Departamento de Laboratorio. Secretaría de Desarrollo Urbano y Obras Públicas.

Carretero, S., Kruse, E., 2014. Iron and manganese content in groundwater of the northeastern coast of the Buenos Aires Province, Argentina. Environ. Earth Sci. 73, 1983-1995. http://http/dx.doi.org/10.1007/s12665-014-3546-5. 
Cinti, D., Poncia, P.P., Brusca, L., Tassi, F., Quattrocchi, F., Vaselli, O., 2015. Spatial distribution of arsenic, uranium and vanadium in the volcanic-sedimentary aquifers of the Vicano-Cimino Volcanic District (Central Italy). J. Geochem. Explor. 152, 123-133. http://dx.doi.org/10.1016/j.gexplo.2015.02.008.

CNA (Comisión Nacional del Agua), 2001. Estudio de evaluación hidrogeológica en el acuífero de Tenancingo, Estado de México. Servicios de Ingeniería e Investigación del Medio Ambiente S.C. (SIIMA) (Contrato SGT-GRB-MEX-01-023-RFI3).

CONAGUA (Comisión Nacional del Agua), 2007. Situación de los acuíferos en la cuenca del río Balsas. Organismo de Cuenca Balsas, Taxco, Guerrero.

Corniello, A., Ducci, D., 2014. Hydrogeochemical characterization of the main aquifer of the "Litorale Domizio-Agro Aversano NIPS" (Campania - southern Italy). J. Geochem. Explor. 137, 1-10. http://dx.doi.org/10.1016/j.gexplo.2013.10.016.

Dassi, L., 2011. Investigation by multivariate analysis of groundwater composition in multilayer aquifer system from North Africa: a multi tracer approach. Appl. Geochem. 26, 1386-1398. http://http/dx.doi.org/10.1016/j.apgeochem.2011.05. 012.

Deutsch, W., 1997. Groundwater Geochemistry. Fundamentals and Applications to Contamination. Lewis Publishers, New York.

Drever, J.I., 1997. The Geochemistry of Natural Waters. Prentice Hall, New Jersey.

Homoncik, S.C., MacDonald, A.M., Heal, K.V., Dochartaigh, B.É.Ó, Ngwenya, B.T., 2010. Manganese concentrations in Scottish groundwater. Sci. Total Environ. 408, 2467-2473. http://dx.doi.org/10.1016/j.scitotenv.2010.02.017.

EPA (Environmental Protection Agency), 2003. National Secondary Drinking Water Regulations. USEPA (816-F-03-016).

EPA (Environmental Protection Agency), 2004. Drinking Water Health Advisory for Manganese. USEPA.

Esteller, M.V., Andreu, J.M., 2005. Anthropic effects on hydrochemical characteristics of the Valle de Toluca aquifer (central Mexico). Hydrogeol. J. 13, 378-390. http://http/ dx.doi.org/10.1007/s10040-004-0395-4.

GEM (Gobierno del Estado de México), 1997. Monografía geológica-minera del Estado de México. Secretaría de Comercio y Fomento Industrial.

González-Abraham, A., Fagundo-Castillo, J.R., Carrillo-Rivera, J.J., Rodríguez-Estrella, R., 2012. Geoquímica de los sistemas de flujo de agua subterránea en rocas sedimentarias y rocas volcanogénicas de Loreto, BCS, México. Bol. Soc. Geol. Mex. 64, 319-333.

Halim, M.A., Majumder, R.K., Nessa, S.A., Hiroshiro, Y., Sasaki, K., Saha, B.B., Saepuloh, A., Jinno, M., 2010. Evaluation of processes controlling the geochemical constituents in deep groundwater in Bangladesh: spatial variability on arsenic and boron enrichment. J. Hazard. Mater. 180, 50-62. http://http/dx.doi.org/10.1016/j.jhazmat. 2010.01.008.

Hounslow, A.W., 1995. Water Quality Data: Analysis and Interpretation. Lewis Pub, New York.

Jalali, M., 2006. Chemical characteristics of groundwater in parts of mountains region, Alvand, Hamadan, Iran. Environ. Geol. 51, 433-446. http://http/dx.doi.org/10. 1007/s00254-006-0338-6.

Jalali, M., 2010. Groundwater geochemistry in the Alisadr, Hamadan, western Iran. Environ. Monit. Assess. 166, 359-369. http://http/dx.doi.org/10.1007/s10661-0091007-5.

Jalali, M., Jalali, M., 2016. Geochemistry and background concentration of major ions in spring waters in a high-mountain area of the Hamedan (Iran). J. Geochem. Explor. 165, 49-61. http://dx.doi.org/10.1016/j.gexplo.2016.02.002.

Kazak, E., Pozdniakov, S., 2010. Sensitivity of model of ferrous iron oxidation by dissolved oxygen in the groundwater system. In: Birkle, P., Torres-Alvarado, I. (Eds.), Water-Rock Interaction. Taylor \& Francis Group, London.

Kegley, S.E., Andrews, J., 1998. The Chemistry of Water. University Science Books, Sausalito, California.

Koh, D-Ch., Chae, G.-T., Kang, B.-R., Koh, G.-W., Park, K.-H., 2009. Baseline geochemical characteristics of groundwater in the mountains of Jeju Island, South Korea: implications for degree of mineralization and nitrate contamination. J. Hydrol. 376, 81-93. http://http/dx.doi.org/10.1016/j.j.hydrol.2009.07.016.

Marrero, R., 2010. Modelo hidrogeoquímico del acuífero de las cañadas del Teide, Tenerife, Islas Canarias. Ph. D. Thesis. Universitat Politécnica de Catalunya, Barcelona.

Medina, C.M., 2011. Priorización de focos de contaminación de agua subterránea mediante una combinación de métodos tradicionales de protección y modelación numérica: acuífero del Valle de Tenancingo. Master Thesis Universidad Autónoma del Estado de México.

Morales-Arredondo, I., Rodriguez, R., Armienta, M.A., Villanueva-Estrada, R.E., 2016. The origin of groundwater arsenic and fluoride in a volcanic sedimentary basin in central Mexico. A hydrochemistry hypothesis. Hydrogeol. J. 24, 1029-1044. http:// dx.doi.org/10.1007/s10040-015-1357-8.

Morán-Ramírez, J., Ledesma-Ruiz, R., Mahlknecht, J., Ramos-leal, J.A., 2016. Rock-water interactions and pollution processes in the volcanic aquifer system of Guadalajara, México, using inverse geochemical modeling. Appl. Geochem. 68, 79-94. http://dx. doi.org/10.1016/j.apgeochem.2016.03.008.

Mukherjee, A., Fryar, A.E., 2008. Deeper groundwater chemistry and geochemical modeling of the arsenic affected western Bengal Basin, West Bengal, India. Appl. Geochem. 23, 863-894. http://http/dx.doi.org/10.1016/j.apgeochem.2007.07.011.

NOM-127-SSA1-1994, 2000. Salud ambiental, agua para uso y consumo humano-límites permisibles de calidad y tratamientos a que debe someterse el agua para su potabilización. DOF (20 de junio de 2000).

NRC US (National Research Council U.S), 1979. Iron/Subcommittee on Iron, Committee on Medical and Biologic Effects of Environmental Pollutants, Division of Medical Sciences, Assembly of Life Sciences, National Research Council. University Park Press, Baltimore.

Ortega-Guerrero, M.A., 2009. Presencia, distribución, hidrogeoquímica y origen de arsénico, fluoruro y otros elementos traza disueltos en agua subterránea, a escala de cuenca hidrológica tributaria de Lerma-Chapala, México. Revista Mexicana Ciencias Geológicas 26, 143-161.

Parisi, S., Paternoster, M., Perri, F., Mongelli, G., 2011. Source and mobility of minor and trace elements in a volcanic aquifer system: Mt. Vulture (southern Italy). J. Geochem. Explor. 110 (3), 233-244. http://http/dx.doi.org/10.1016/j.gexplo.2011.06.010.

Parkhurst, D.L., Appelo, C.A.J., 2013. Description of input and examples for PHREEQC version 3-a computer program for speciation, batch-reaction, one-dimensional transport, and inverse geochemical calculations. In: U.S. Geological Survey Techniques and Methods, Book 6, Chap. A43, 497 p., available only at. http://pubs. usgs.gov/tm/06/a43.

Puigdomenech, I., 2004. Make Equilibrium Diagrams Using Sophisticated Algorithms (MEDUSA) Program. Inorganic Chemistry Department. Royal Institute of Technology, Stockholm, Sweden.

Rahman, M.A.T.M.T., Majumder, R.K., Rahman, S.H., Halim, M.A., 2011. Sources of deep groundwater salinity in the southwestern zone of Bangladesh. Environ. Earth Sci. 63, 363-373. http://dx.doi.org/10.1007/s12665-010-0707-z.

Senderos, A.J., 2001. Estudio Microbiológico de las Incrustaciones y Corrosiones en Captaciones de Agua Subterránea. Ph. D. Thesis Universidad Complutense de Madrid.

Smith, M., Roychoudhury, A.N., 2013. Mobilization of iron from rocks in a fractured aquifer: lithological and geochemical controls. Appl. Geochem. 31, 171-186. http:// dx.doi.org/10.1016/j.apgeochem.2013.01.002.

Sonkamble, S., Sahya, A., Mondal, N.C., Harikumar, P., 2012. Appraisal and evolution of hydrochemical processes from proximity basalt and granite areas of Deccan Volcanic Province (DVP) in India. J. Hydrol. 438-439, 181-193. http://http/dx.doi.org/10. 1016/j.jhydrol.2012.03.022.

Stumm, W., Morgan, J.J., 1996. Aquatic Chemistry. Chemical Equilibria and Rates in Natural Waters, 3rd. Ed. Wiley-Interscience Publication, New York.

Tóth, J., 1999. Groundwater as a geologic agent: An overview of the causes, processes, and manifestations. Hydrogeol. J. 7, 1-14. http://dx.doi.org/10.1007/ s100400050176.

USSL (US Salinity Laboratory), 1954. Diagnosis and Improvement of Saline and Alkali Soils. US Department of Agriculture Hand Book (No 60).

Vivona, R., Preziosi, E., Madé, B., Giuliano, G., 2007. Occurrence of minor toxic elements in volcanic-sedimentary aquifers: a case study in central Italy. Hydrogeol. J. 15, 1183-1196. http://dx.doi.org/10.1007/s10040-007-0169-x.

Weng, H.X., Qin, Y.C., Chen, X.H., 2007. Elevated iron and manganese concentrations in groundwater derived from Holocene transgression in the Hang-Jia-Hu Plain, China. Hydrogeol. J. 15, 715-726. http://http/dx.doi.org/10.1007/s10040-006-0119-z.

Wilcox, L.V., 1955. Classification and use of irrigation waters. US Department of Agriculture, Washington, DC, USA Circular 969. 